\title{
Acidic Shell Proteins of the Mediterranean Fan Mussel Pinna nobilis
}

Frédéric Marin, Prabakaran Narayanappa, and Sébastien Motreuil

UMR CNRS 5561 “Biogéosciences”, Université de Bourgogne, 6, Boulevard Gabriel, Dijon 21000, France 


\begin{abstract}
In molluscs, the shell secretion process is controlled by a set of extracellular macromolecules collectively called the shell matrix. The shell matrix, which is produced by the mantle epithelial cells during mineralization, is predominantly composed of proteins, glycoproteins, acidic polysaccharides, and chitin that precisely regulate the deposition of calcium carbonate outside the mantle cells. In the present paper, we focus on the shell of Pinna nobilis, the giant Mediterranean fan mussel, usually considered as a model for studying molluscan biomineralization processes. $P$. nobilis exhibits indeed a nacro-prismatic shell, the outer layer of which is constituted of the so-called "regular simple calcitic prisms," according to Carter and Clark (1985). We review here the microstructural characteristics of the prisms and nacre and the biochemical properties of their associated matrices. In particular, the calcitic prisms of $P$. nobilis are characterized by a cortege of unusually acidic intraprismatic proteins, while the ones of the nacreous layer seem less acidic. A brief description of the molecular characterization of three acidic proteins, caspartin, calprismin and mucoperlin, is given. In particular, we show that extremely acidic intracrystalline proteins such as caspartin interact with calcium carbonate at different scales, from micrometric to crystal lattice levels.
\end{abstract}

\title{
13.1 Biomineralization of the Molluscan Shell, a Brief Overview of the Mechanism
}

In the metazoan world, molluscs are often considered as the master controllers of biomineralization processes, and their shell represents the most remarkable example of a biologically controlled mineralization produced outside living tissues by a calcifying epithelium (Simkiss and Wilbur 1989).

The organ responsible for the mineral deposition and shell formation is the mantle, the thin epithelium that envelopes the soft body of molluscs, and which is in contact with the growing shell. More precisely, according to classical views, the calcification takes place in a closed space, the extrapallial space, located at the interface between the mantle tissues, the leathery periostracum and the growing shell itself. The shell emerges from a subtle chemistry between the precursor mineral ions, i.e., calcium, bicarbonate, and minor elements such as magnesium or strontium that are extruded in the extrapallial space, and the numerous macromolecular extracellular components produced by the mantle epithelial cells, i.e., proteins and polysaccharides. All these components react in a well-coordinated manner. This self-assembling process produces solid and compact microstructures such as nacre, prisms, crossed-lamellar, foliated, or homogeneous textures (Carter 1990).

In the recent years, numerous new data have completed this classical view. The most recent advances deal more particularly with the structure of shell biominerals at the nanoscale (Oaki and Imai 2005), and with the identification of an increasing number of shell matrix proteins (Marin et al. 2008). Although the organic matrix represents usually less than $5 \%$ of the shell weight, it is however the major component that controls different aspects of the shell formation processes (Addadi 
et al. 2006). Until recently, the classical paradigm was to consider that the control of shell synthesis at the biocrystal scale was performed primarily by two main mechanisms: crystal nucleation (and subsequent elongation) and growth inhibition (Wheeler et al. 1988). New concepts and emerging models try now to translate a more complex and dynamic reality, which is remarkably illustrated by the wide variety of shell proteins, characterized in the last few years (Marin et al. 2008). These proteins cover a broad spectrum of $\mathrm{pI}$, from very acidic to very basic. The primary structure of a number of them is composed of different modules, suggesting that these proteins are multifunctional. Some of them exhibit enzymatic activities. Others may be involved in cell signaling. Some others have remarkable crystalbinding properties. Nowadays, the extracellular calcifying shell matrix appears as a whole integrated system, which regulates protein-mineral and protein-protein interactions as well as feedback interactions between the biominerals and the calcifying epithelium that synthesized them.

In the present paper, we focus on a peculiar model organism, Pinna nobilis, the Mediterranean fan mussel. By many aspects, the choice of this species may appear odd. This species cumulates indeed few handicaps: first, it is a strongly protected species, a fact which does not facilitate field sampling; second, studies on the physiology and reproduction of Pinna nobilis are sparse, and several field and laboratory data have still to be generated on these topics; third, there are no extensive genetic data available, and, as far as we know, there are no coming initiative aiming at sequencing the genome, or, at least, aiming at obtaining transcriptomic data (ESTs). At last, and this last fact explains the situation, the world scientific community, which works - temporarily or full-time - on Pinna nobilis is extremely limited: a rough estimation oscillates between two and three dozens of scientists on a world scale. These obstacles would appear unsurmountable, if they were not compensated by the fact that Pinna nobilis, from a historical viewpoint, is considered as a model organism in biomineralization, in particular, by the production of its outer shell layer, made of "regular simple calcitic prisms," the structural and molecular characteristics of which are detailed in the present review. Because the calcitic prisms of Pinna nobilis are large and exhibit remarkable optical properties, they represent fascinating objects, for trying to understand how molluscs are able to control their biocrystal synthesis over molecular to millimeter scales. We believe that they may be a source of inspiration for the analysis of structural hierarchy in biomineralization and for biomimicry purpose.

\subsection{Pinna nobilis, a Model for Understanding Molluscan Shell Formation}

\subsubsection{Presentation of Pinna nobilis}

Also called noble pen mussel, rough pen shell, fan mussel, fan shell, razor fish, seawings or wing-shell, Pinna nobilis is the biggest Mediterranean bivalve, and 
together with the Giant clam Tridacna gigas, one of the biggest molluscs in the world: its size currently exceeds $80 \mathrm{~cm}$ and may reach $1 \mathrm{~m}$. Its longevity is estimated to be around 30 years.

This species is endemic to the Mediterranean sea and can be observed along different coasts, in particular along the "côte d'Azur" and around Corsica in France (Moreteau and Vicente 1982; Medioni and Vicente 2003), the Spanish coast and around the Balearic Islands (Garcia-March 2003; Garcia-March et al. 2007), on the Tunisian (Rabaoui et al. 2008), Italian (Centoducati et al. 2007), Greek (Katsanevakis 2007), and Crete (Katsanevakis and Thessalou-Legaki 2009) coasts. Pinna nobilis is also well represented in the Adriatic, along the Croatian coast (Zavodnik 1967; Siletic and Peharda 2003). This species, which lives in the infralittoral domain between $0.5 \mathrm{~m}$ and $30 \mathrm{~m}$ depth, grows almost exclusively in the meadows of the seagrass Posidonia oceanica. In its natural environment, the shell of Pinna nobilis has a very characteristic living position: the pointed anterior end of the shell - about one-third - is buried in the soft sediment and the elongated fan-shaped shell is erected more or less vertically. Byssal threads anchor the animal to underlying stones or other objects. Pinna nobilis lives in small grouping: the populations are usually patchy and sparse (Katsanevakis 2007).

Although its size rendered it attractive, Pinna nobilis had limited uses throughout history as a marine resource: during the Phenician period, and later, during the Roman times and until the first world war in Italy and in Malta, the long and solid byssus (up to $20 \mathrm{~cm}$ ) - the"sea-silk" - was cut and collected for the making of tissues, of gloves, or of hats of priceless value (Brisou 1985; Maeder and Halbeisen 2001). Although of moderate taste value, the soft tissues of Pinna nobilis were consumed in Malta, in Corsica and in former Yougoslavia. The thick nacre of adult specimens was used for manufacturing clothes buttons, in particular in Sicilia, in Malta, and in the South of Italy. Natural brown-red pearls of respectable size, known as the pen shell pearl can be found in adult specimens, but they have no commercial value (Gauthier et al. 1994). These pearls, known as the prism pearls (Schmidt 1932), are naturally stained by carotenoid pigments (Karampelas et al. 2009). Until recently, the full empty shell of juvenile or adult specimens was collected for souvenir purposes. Nowadays, Pinna nobilis is considered as an endangered species: since 1992, it is registered in the official list established by the European Union for the conservation of natural habitats and of wild fauna and flora (Off. J. E. C. L206, 22.7.1992). In some spots (Port-Cros field, mission "Poseidon") where populations could be followed during three decades (Vicente 2003), the situation was particularly dramatic few years ago. In protected areas, nowadays, populations tend to reconstitute again (Medioni and Vicente 2003; Foulquié and Dupuy de la Grandrive 2003). However, this growth is fragile, and populations are vulnerable to catastrophic climatic events such as the recent storm (May 2010) that broke on Côte d'Azur (S. Motreuil, personal communication, 2010). Attempts to capture and recruit larvae on artificial devices, to let them grow in controlled conditions and to reimplant juveniles in natural environment may be the best option for reconstituting natural populations (De Gaulejac and Vicente 1990; Vicente 2003; Cabanellas-Reboredo et al. 2009). 


\subsubsection{Physiology, Development, and Reproduction of Pinna nobilis}

There has been a limited number of recent studies on the physiology and reproduction of Pinna nobilis (De Gaulejac 1993; Riva 2003). Most of them are due to the CERAM (Centre d'Etude des Ressources Animales Marines) and to the Institut océanographique Paul Ricard (Vicente, De Gaulejac, Riva, and coworkers). The general metabolism of Pinna nobilis, in particular respiration and filtration, seems to be rather low compared to other bivalves like the mussel, the edible oyster or the clam (Vicente et al. 1992). To our knowledge, no physiological studies were performed in relation with shell calcification: in particular, although hemocytes of Pinna nobilis were precisely described (Henry et al. 1992), no link was established between the presence of these cells in mantle tissues and the transport of calcium or of amorphous calcium carbonate granules for shell mineralization.

Pinna nobilis is a successive hermaphrodite, with an asynchronous gamete maturation (De Gaulejac et al. 1995a, b; Vicente 2003), which avoids self-fertilization. Its sexual cycle is divided into two phases: a sexual repose from October to March, an active sexual period for the rest of the year, with in particular a succession of alternate spawning and fast gametogenesis from June to August. Ovocytes are fertilized in full seawater. After fecondation, the development of $P$. nobilis follows the classical developmental pathway for bivalves, namely, a trochophore larval stage (ciliated larva), and a veliger stage (swimming larva). When the veliger larva gets fixed of a substratum, the metamorphosis operates (loss of the velum, reorganization of the internal organs), and the larva transforms into a juvenile specimen. The larval shell starts to be secreted early during development, during the trochophore stage. However, unlike works on other bivalves like Mytilus or Ostrea, there were no precise studies on the shell ontogeny of $P$. nobilis.

\subsubsection{Systematic Position of Pinna nobilis and Ancestry of the Pinnid Family}

For the taxonomical position of Pinna nobilis within the Mollusca phylum, we refer to the classification of Giribet (2008), based on morphological and molecular characters, and to the molecular phylogeny established by Steiner and Hammer (2000) for Pteriomorphian bivalves. P. nobilis is a bivalve which belongs to the Pteriomorphia subclass. This heterogeneous clade is nowadays considered as the sister group of the heteroconchs, which itself comprises paleoheterodont (freshwater mussels) and heterodont (clams) bivalves. The Pteriomorphia subclass comprises nine superfamilies (Mytiloidea, Pterioidea, Pinnoidea, Arcoidea, Limoidea, Ostreoidea, Plicatuloidea, Pectinoidea, and Anomioidea, see Steiner and Hammer 2000), the three first of them being characterized by typical nacroprismatic shell texture. P. nobilis belongs to the Pinnoidea superfamily, and to 
the Pinnidae family, which comprises three living genera, Atrina, Pinna, and Streptopinna, and seven fossil ones. The Pinnidae family comprises 123 living and fossil species and subspecies. The Pinna genus itself comprises 75 extant and extinct species and subspecies. The living species all together have a broad geographic repartition all over the world, with a predilection for warm waters. For a detailed list of the species that belong to the Pinna genus, we refer to the following Web site: http://zipcodezoo.com/Key/Animalia/Pinna_Genus.asp.

According to Taylor et al. (1969) and Carter (1990), the Pinnidae family is of Paleozoic origin, and appeared at the basal Carboniferous. Genera like Aviculopinna, Meekopinna, or Pteronites, and species like Pinna peracuta or Pinna flexistria are attested to be of Carboniferous age. The Pinnid family may derive from Devonian pterineids, such as Leptodesma (Carter 1990). The family has a discontinuous fossil record. The well-known Trichites genus, characterized by an extremely thick calcitic prismatic layer, is frequent in the calcareous sediments of the Upper Jurassic (Tithonian).

\subsection{Shell Formation Process}

\subsubsection{Shell Growth}

As shown in Fig. 13.1, the shell of Pinna nobilis has a typical elongated triangular shape with a sharp anterior. The shell is equivalve. The color of the shell is light brown for juvenile specimens and becomes brown-red when the shell thickens. This coloration, localized exclusively in the outer shell layer, is due to a mixture of carotenoid pigments (Gauthier et al. 1994), the exact molecular characterization of which has still to be done. In juvenile specimens, the shell is translucent (Fig. 13.1b), but becomes opaque with age.

Like several bivalves of Mediterranean or temperate zones, the shell growth of $P$. nobilis follows a seasonal pattern: the shell grows slowly during the cold months and has a maximal growth during late spring and early summer (Katsanevakis 2007). This optimum may result from a combination of temperature and food availability. When the water temperatures exceed a threshold (around $29^{\circ} \mathrm{C}$ ) during August, the shell growth slows down or stops. The growth of the shell, which has been monitored during the entire life of several specimens, follows a classical Von Bertalanffy model, with a rapid almost linear growth during the first 3 years, and a progressive decrease of the growth rate until reaching a plateau (Moreteau and Vicente 1982). An equation was formulated to describe the mean shell growth:

$\mathrm{H}_{t}=86.3\left[1-\mathrm{e}^{-0.053(t+0.22)}\right]$ where $\mathrm{H}_{\mathrm{t}}$ is the full length, and $\mathrm{t}$, the age in months.

According to this equation, a 1-year-old specimen reaches $12 \mathrm{~cm}$, a 2-year-old, $22 \mathrm{~cm}$, a 3-year-old, $30 \mathrm{~cm}$. At these early stages, the shell remains very thin; it is extremely fragile and translucent. 20-year-old specimens are about $80 \mathrm{~cm} \mathrm{long}$, and the shell thickness is about $1 \mathrm{~cm}$ at the tip. More recent studies on different 

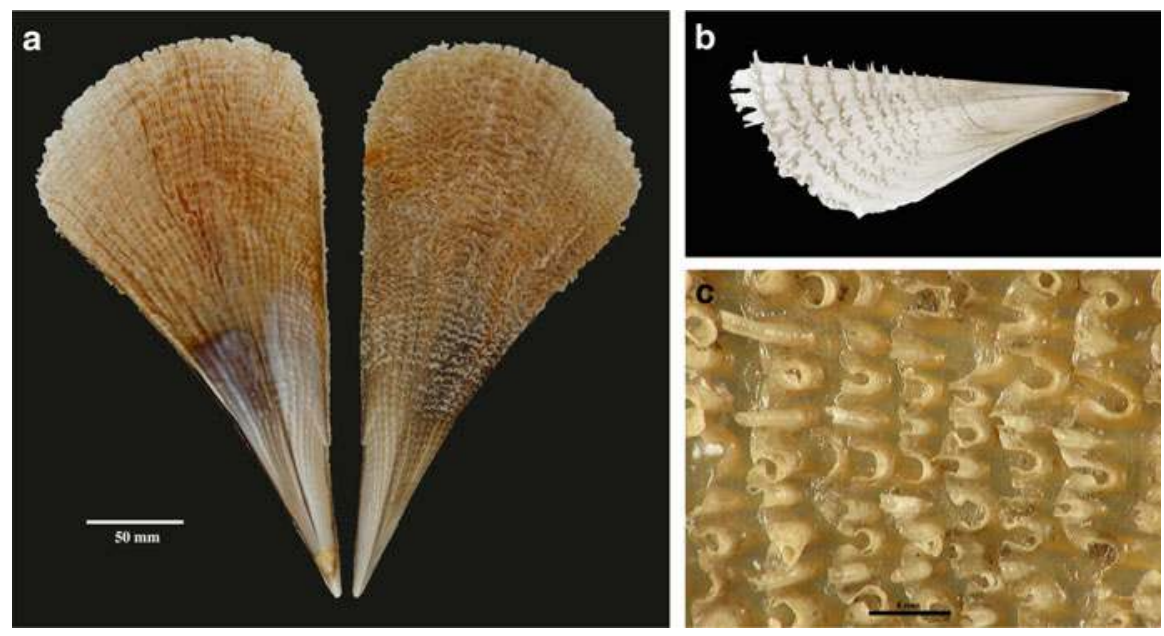

Fig. 13.1 The shell of Pinna nobilis. (a) shell of a juvenile specimen, approx. age 3-year-old, size $300 \mathrm{~mm}$; note that the internal nacreous layer, in shiny white, is restricted to the first half of the shell. The outer calcitic prismatic layer is covered with spines. (b) shell of a very young specimen, age about 5-6 months old, size $60 \mathrm{~mm}$; the shell is almost transparent. (c) detailed view of the delicate calcitic hollow spines of the outer shell layer, among juvenile specimens; with aging, the spines progressively erode

populations showed that the growth kinetics is submitted to slight variations (Garcia-March et al. 2002; Rabaoui et al. 2007), according to environmental parameters, including temperatures, water turbidity, depth, nutrient fluxes.

Because the growth of the shell is rapid during the first years (a daily growth above $0.3 \mathrm{~mm}$ for a 1-year-old specimen), it is likely that juvenile specimens allocate an important part of their energetic budget to the calcification of their shell, which, in other words, may mean that other metabolic activities are kept low. However, to our knowledge, there are no precise data in the literature on this aspect of the physiology of Pinna nobilis.

The shells of young specimens are characterized by the formation of thin calcitic hollow spines, produced by the pleated border of the mantle (Fig. 13.1a-c). These spines, which are extremely sharp, fragile and brittle, are regularly distributed on all the outer surface of the two valves (Fig. 13.1c), according to the shell growth lines. When aging, they are progressively eroded (Cosentino and Giacobbe 2006). In 3 -year-old shells, one observes a gradient of spine erosion from the shell border where spines are newly formed to the shell tip, where they are fully abraded (Fig. 13.1a). In specimens older than 4-5 years, the spines are fully eroded. The spines do not have a biomechanical function for the shell. They constitute however a defensive tool against predation and biting of young specimens by fishes. They also constitute anchoring points for the settlement of epibiontic algal communities, which provide a camouflage to the shell in Posidinia meadows. At last, the spines shelter a large community of epizoobiontic molluscs (Giacobbe 2002; Cosentino 
and Giacobbe 2007a, b; Rabaoui et al. 2007, 2009). Thus, the spines constitute an efficient adaptation to passively and actively prevent predation on juvenile specimens, the shell of which is particularly fragile.

\subsubsection{Shell Microstructures}

The shell of $P$. nobilis exhibits the typical bilayered calcified structure (in addition to the outer organic periostracum), found in several pteriomorphid bivalves. The periostracal layer is visible particularly in juvenile specimens, but tends to quickly erode in older specimens. The outer mineralized layer is calcitic and composed of "simple" prisms, developed perpendicularly to the surface of the shell. The "simple prisms" terminology is doubly misleading. First, "simple" would refer to an elementary structure, but we show below (Sect. 3.4) that the prisms of P. nobilis exhibit a structural hierarchy, which is everything but simple. Second, "prism" designates very different objects in molluscan shell microstructures, like the tiny oblique prisms of the edible mussel, the prisms of the freshwater mussel, the composite prisms of the clam, and those of the pearl oyster (Carter 1990). These objects are brought together under a single term, but it seems obvious that they are not synthesized through a unique pathway.

The internal layer is light grey and aragonitic. It exhibits the iridescence characteristic of nacreous textures. While the outer prismatic layer covers the entire shell, the nacreous layer is restricted to the area between the adductor muscle scars, which represents about one-half of the shell height. By analogy with more studied nacroprismatic bivalve models such as Pinctada (Sudo et al. 1997), the fact that the shell is bilayered means that the mantle epithelium that produces the shell is not homogeneous: the epithelial cells located at the border of the mantle are dedicated to the synthesis of the prismatic layer while epithelial cells situated more proximally from the shell tip secrete the nacre layer. However, histological studies should be done to confirm this finding.

From a historical perspective, it is remarkable to notice that the shell microstructure of Pinna sp., which is a rather uncommon genus, was extensively described as early as the beginning of the ninetieth century, with the successive works of De Bournon (1808), Gray (1835), Bowerbank (1844), Carpenter (1844), Leydolt (1856), Rose (1858). During the early twentieth century, other microstructural studies followed, in particular those of Biedermann (1901), Römer (1903), Karny (1913), Cayeux (1916), Schmidt $(1923,1924)$ and of course, the classical study of Boggild (1930).

With the development of the electron microscopy in the thirties, and the conception of the scanning electron microscope after WWII, Pinna sp. was also the subject of different studies and monographies, including papers from Grégoire (1967), Wise (1970), Mutvei (1970), Wada (1972, 1980). Let us cite the extensive work of Taylor and coworkers (1969) on bivalves. In the eighties, the shell microstructures of Pinna sp. were described through series of papers of Cuif and coworkers (1980, 1983a, b, 1985, 1987a, b), Cuif et Raguideau (1982), Nakahara et al. (1980), Carter 
and Clark (1985) and finally, the voluminous treatise on microstructures of Carter (1990). Recent microstructural, mineralogical, and physical studies include the works of Dauphin et al. (2003), of Checa et al. (2005), and of Esteban-Delgado et al. (2008).

\subsubsection{The Calcitic Prisms of Pinna nobilis}

The data on the shell ontogeny of Pinna nobilis are not known, and all our knowledge derives from developmental studies performed on bivalves with similar shell texture, like Mytilus (Medakovic 2000). Following this general scheme, the early shell appears during the trochophore stage, and is secreted by the transitory shell gland, the group of cells resulting from the invagination of the ectoderm (Kniprath 1981). After the production of an organic lamella - the future periostracum - by the shell gland, the first mineralization is deposited between the lamella and the shell gland itself. By analogy with other better-studied bivalves, it is likely that the first minerals produced are amorphous (Mao Che et al. 2001; Weiss et al. 2002). Then, the prismatic layer appears, by growing inward from the organic lamella. At a later stage (veliger or post-metamorphosis?), the deposition of the nacreous layer starts in the hinge area, while the prismatic layer continues its lateral extension on the two valves.

Poorly investigated from an ontogenetic viewpoint, the prismatic layer has been well studied in juvenile or adult specimens. As described by Boggild (1930), the prisms, when seen in transverse section, "are very regular and, at the same time, distinct, with an interprismatic substance. The orientation of the optic axis is unusually regular, parallel to the direction of the prisms." Taylor and coworkers (1969) distinguished two types of prisms, the simple ones and the composite ones. Those of $P$. nobilis belong to the first category. These authors gave a more precise definition of the prisms: "simple calcite prisms, arranged with their crystallographic c axes normal to the layer surface. The prisms are larger than in any other family... and the prismatic layer as a whole can be several millimeters thick." In their scrupulous attempt to classify molluscan shell microstructures, Carter and Clark (1985) recognized several types of prismatic structures, defined as "mutually parallel, adjacent structural units $\left(1^{\text {st }}\right.$ order prisms) that do not strongly interdigitate along their mutual boundaries. The first order prisms are generally longer than they are wide." Those of Pinna nobilis are defined as simple prismatic structures, "in which each $1^{\text {st }}$ order prism shows a non-spherulitic prismatic and non-composite prismatic substructure. The boundaries of adjacent $1^{\text {st }}$ order prisms are well defined and generally noninterdigitating". . and further "they are commonly oriented with their length axes perpendicular to the plane of the shell layer." Furthermore, Carter and Clark (1985) introduced a subcategory, of regular simple prismatic structures, in which "each $1^{\text {st }}$ order prism is columnar and has a more or less equidimensional (non-elongated) polygonal cross sectional shape. The prism shapes and their diameter appear rather uniform in section perpendicular to the prism length axes, although the prism 

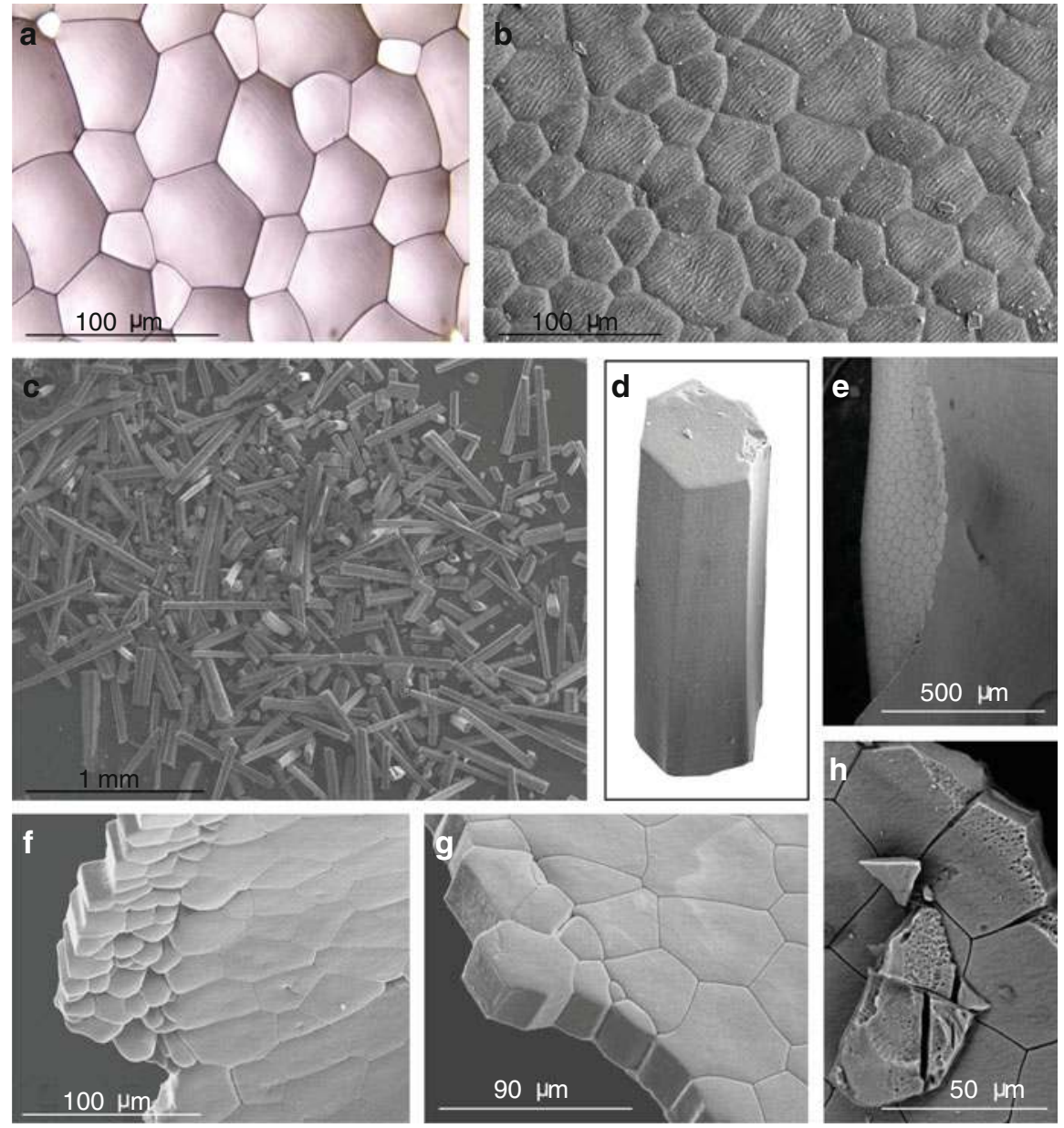

Fig. 13.2 The prismatic calcitic layer of Pinna nobilis. (a) thin section (about $30 \mu \mathrm{m}$ ) of the prismatic layer, observed with an optical microscope. Ridges are visible on the prisms. (b) similar view, taken with a SEM. The ridges are clearly visible. Note that they all have the same orientation. (c) isolation of single calcitic prisms with sodium hypochlorite. (d) one isolated prism. (e) macroscopic view of a hollow spine of the shell of a few-months-old specimen. The whole spine is constituted of flat prisms. (f-h) newest synthesized prisms at the edge of a 6-month-old shell. Prisms look like tiles. (h) slight etching with EDTA 1\% (w/vol), 5 min

diameters generally increase from the outer to the inner parts of the shell through geometric selection." The calcitic prisms of $P$. nobilis belong to this subcategory.

When observed in cross section, the prisms of $P$. nobilis exhibit a polygonal section, generally penta- to heptagonal (Fig. 13.2). Consequently, in surface view, the prismatic layer exhibits a typical "honeycomb" structure pattern (Taylor et al. 1969), with the prisms maintained together by an interprimatic insoluble organic sheath, that old authors assimilated to conchiolin (Grégoire 1967). 
The thickness of this sheath is less than $1 \mu \mathrm{m}$ (we estimate that it varies between 0.8 and $1 \mu \mathrm{m}$, except at the triple junctions where it is thicker). This sheath is structurally coherent and flexible: when the prisms are partly or totally dissolved with EDTA or with weak acid, the sheath remains in place. Because the sheath represents a high proportion of the shell (about 4\% wt/wt) and because of its honeycomb structure, it confers to the shell a surprising bending capability, in particular, in juvenile specimens. On the other hand, the prismatic layer of $P$. nobilis can be entirely dissociated in single prism units, by selectively degrading the organic sheath. The most classical chemical reagent used for that purpose is dilute sodium hypochlorite. In our lab, we currently treat fragments of prismatic layers for few days with a $0.26 \%$ of active chlorine solution (dilution ten times from a commercial solution). The single prisms can be subsequently collected and extensively washed with water on a 5 - $\mu \mathrm{m}$ filter. Removal of the organic sheath has also been successfully performed by enzymatic proteolysis with an enzyme - like pronase $\mathrm{B}$ - that exhibits a broad spectrum of proteolytic activity (Keller 1981; Keller and Dauphin 1983).

\subsubsection{Ultrastructure of the Prisms of P. nobilis and Complexity of the Organo-mineral Interactions}

By many aspects, the calcitic prisms of Pinna nobilis appear as paradoxical objects, because they conciliate an apparent crystallographic simplicity and an ultrastructural complexity. The nature of the calcitic prisms of $P$. nobilis is revealed by investigating the crystallographic properties on single prisms, or on prisms preparations observed in cross sections, in combination with analysis of their substructures. As mentioned by Carter (1990, p 213), "the calcitic, regular simple prisms in pinnid shells are commonly optically homogeneous with perfect, monocrystalline, non-grainy extinction under crossed polarized light." This means that each prism behaves like a single crystal, with a single extinction (Wada 1961; Cuif and Raguideau 1982). This optical property is confirmed by X-ray diffraction on single prism (F. Marin, unpublished data, 2003). This technique demonstrates that one prism diffracts like a single crystal.

Although the prisms of $P$. nobilis are optically homogeneous, they are neither "single" nor "simple" crystals, and many studies have underlined their complex substructures that superimpose at different scales. What makes their peculiar ultrastructural complexity is the presence of an intraprismatic organic matrix, the characteristics of which are detailed in Sect. 4.

Decalcification experiments aiming at dissolving the prisms and keeping the organic sheaths show that these sheaths exhibit a transverse striation (Grégoire 1967). To this striation, perpendicular to the long axis of the prisms, corresponds a striation on the prisms themselves (Fig. 13.2), visible in longitudinal view. This striation marks the successive growth plans. In spite of the presence of the sheath that separates each prism from its neighbors, the growth lines can be followed for millimiters throughout the length of the shell section (Fig. 13.2). 
Pyrolysis experiments performed on single prisms showed that they could be entirely dissociated in minute flat crystals (Frérotte 1987). In an oversimplified view, one could consider that each single prism is constituted of a pile of numerous flat crystallites - intercalated with layers of organic material - that are deposited layer per layer. However, as noted by Cuif and coworkers (1983a, b), this view is completely deceptive, for at least two reasons: (1) The relationships between the organic and the mineral phases are much more complex than a simple alternation between organic and mineral layers. (2) The so-called "elementary" crystals produced by pyrolysis are not homogeneous, but they have a micro-granular texture; this suggests that they are themselves constituted of nanocrystals, which exhibit the same crystallographic orientation. Such an organization of "single crystals" in elementary nanoblocks has been observed for nacre tablets (Oaki and Imai 2005), and may represent a universal rule in biomineralization.

Whatever the organization of the intraprismatic matrix, whatever the size and shape of the elementary units that constitute each prism, all these units exhibit exactly the same optical orientation of their three axes, which is, by itself, absolutely remarkable. This explains the "monocrystal" appearance of each single prism.

The set of experiments performed by Cuif and coworkers, by using different surface treatments (proteolytic digestion, bacterial treatment, slight decalcification, and fixation) showed different ultrastructural aspects of the distribution of the intracrystalline matrix (Cuif et al. 1981; Cuif and Raguideau 1982; Cuif et al. 1983a, b, 1985, 1987a). First, in accordance with the striation observed on the surface of each prism, the intracrystalline organic network exhibits a periodicity, which is perpendicular to the prism axis. In cross section, although periprismatic sheaths separate contiguous prisms, this periodicity, which corresponds to cycles of mineral deposition, is found from prisms to prisms. More surprising was the visualization by Cuif and coworkers of a longitudinal organization of the prisms. By using appropriate treatments with glutaraldehyde/acetic acid/alcian blue, they observed a longitudinal periodicity of the organic network. This periodicity is not strictly parallel to the axis of the prisms, but slightly oblique. This longitudinal organization of the matrix is correlated to the presence of ridges (that look like "ripple-marks") in the internal side of the prisms observed in section perpendicular to the prisms axis (Fig. 13.2b). It is striking to observe that these ridges are parallel in a single prism, but also parallel from prism to prism. Cuif suggested that these ridges result from the intersection of the periodic plans of the intracrystalline network and of the plan perpendicular to the prism axis. So far, the significance of the longitudinal organization of the intracrystalline matrix remains obscure.

\subsubsection{The Prism/Nacre Transition and the Nacreous Layer}

The transition zone between the prismatic and the nacreous layer is rather abrupt (Cuif et al. 1985). It is marked by the formation of an intermediate layer, about $50 \mu \mathrm{m}$ thick (Fig. 13.3a, b). We sometimes observed that the thickness of this layer 

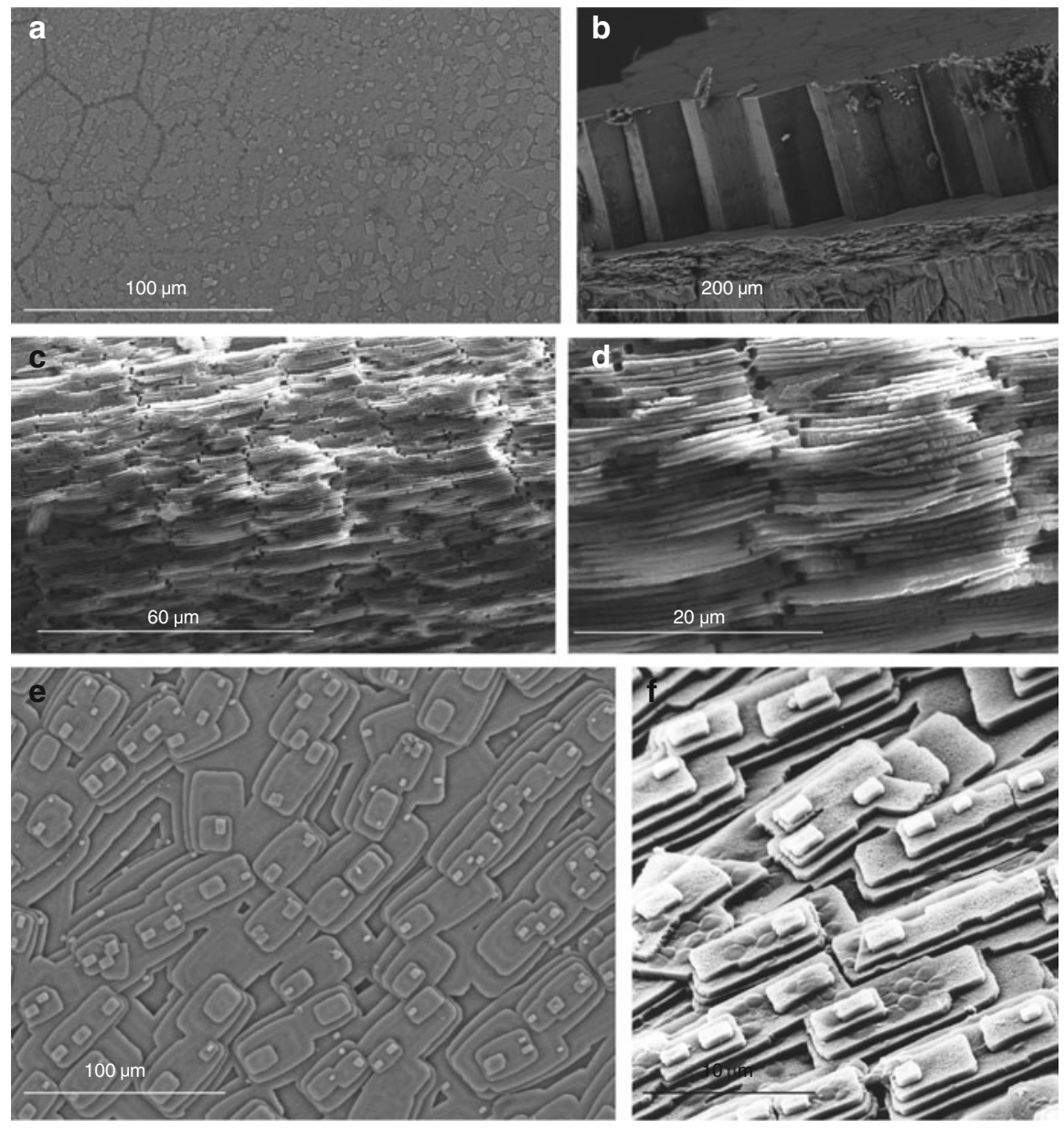

Fig. 13.3 Prisms-nacre transition and the nacreous layer. (a) prisms-nacre transition, observed from the internal shell surface. The prisms are on the left, the nacre, on the right. The prisms are progressively covered by a nacreous layer. (b) cross section of a 6-month-old shell. The prisms are on the top, the nacre below. (c-d) cross section through the nacreous layer. The nacre exhibits the typical "row stack nacre" microstructure, observed in the Pinnid family. (e-f) nacre tablets, seen from the internal shell surface (photo (f) Caseiro J, Gauthier JP). The nacre tablets of Pinna nobilis are rectangular. They do not show the brickwall pattern observed in the pearl oyster nacre, for example

is reduced to $10-20 \mu \mathrm{m}$. This intermediate brownish layer is essentially organic and insoluble. Although of homogeneous aspect once sealed by the subjacent nacreous layer, it has been shown that this layer results from the coalescence of polygonal organic elements during its synthesis (Cuif et al. 1985). By many aspects (insolubility, color), the intermediate layer exhibits similarities with the periostracal layer, and may correspond to chitino-proteinaceous complexes resulting from a quinonetanning process. This layer seals the prismatic layer and represents the template for 
the deposition of nacreous crystallites. As we will see in the next paragraph, the transition layer marks the profound difference of the secretory regime between the mantle cells involved in prisms formation and those involved in nacre deposition.

In Pinna nobilis, as mentioned before, the nacreous layer is restricted to the area comprised between the two muscle scars, about one-half of the shell. In young specimens (2-3 years old), the nacre layer is extremely thin (not more than $2-3 \mathrm{~mm}$ ) and translucent. In old specimens ( $>20$ years), the nacreous layer is opaque and reaches a thickness of about $10 \mathrm{~mm}$ in the anterior tip. Taylor et al. (1969) proposed a general evolutionary trend toward the reduction of the nacreous layer in the Pinnidae family: the ancestral type, which would be nowadays represented by Atrina, exhibits indeed a more expanded nacre layer, while this layer is residual in the most derived Streptopinna genus, Pinna constituting an intermediary stage. This trend toward a reduction of the nacreous layer, if it is verified, would be in agreement with the finding of Palmer (1992), i.e., microstructures like nacre, which have a higher energetic cost to produce, are consequently disadvantaged from an evolutionary viewpoint. Alternatively, it may also correspond to different modes of life, implying different mechanical requirements for the shell.

The fact that the nacreous layer covers only one-half of the shell has an important implication on the geometry of the calcification process: it means that the mineralization fronts of nacre and of prisms are distant from each other. In other words, the mantle epithelial cells that secrete the ionic and macromolecular components for nacre deposition are physically remote (several centimeters in a 2-year-old specimen) from those that initiate the prisms at the shell edge. It also means that the cells involved in the prisms extension, i.e., in the increase of the thickness of the prismatic layer, constitute an extremely large zone of the mantle tissue.With these geometrical constraints, Pinna nobilis differs considerably from Mytilus, Pinctada, or Unio models.

The nacreous layer of $P$. nobilis is rather atypical, and does not correspond to the classical "brickwall texture" (sheet nacre) with consecutive tablets arranged in staggered rows, found in most pterioid, mytiloid, and unionoid bivalves (Wise 1970). The nacre of Pinna nobilis is indeed defined as "row-stack nacre" (Wise 1970; Carter and Clark 1985) and is described as a "nacreous structure in which mutually parallel elongate tablets show vertical stacking in vertical sections perpendicular to their length axes, and brick wall and/or stair step stacking in vertical sections parallel to their length axes. Row stack nacreous structure is well developed in the bivalve Pinna, where it enhances directional flexibility of the shell." In cross section, as shown in Fig. 13.3c-d, nacre elements appear as flexuous flat tablets, $0.5-0.8 \mu \mathrm{m}$ thick and 15-20 $\mu \mathrm{m}$ long, which exhibit a pseudocolumnar disposition. This vertical disposition, which was remarkably described a long time ago by Rose (1858), then by Schmidt (1924, Fig. 48, Tafel 4, "Vertikalschichtung"), appears different, larger, and slightly less structurally regular than that found in haliotid gastropods e.g., but has some similarities with that of Nucula. Vertical sections show the more or less columnar alignments of the successive nacre laminae (Fig. 13.3c-d). When observed from above on the 
mineralization front (Fig. 13.3d), newly formed minute nacre crystals have a typical quadrangular shape and are oriented in the same direction. Proteolytic treatments (Cuif et al. 1983a, b, 1985) revealed the ultrastructural organization of the nacre crystallite and highlighted their composite nature. In particular, it showed that each nacre crystallite is composed of minute granular elements (about $100 \mathrm{~nm}$ ), which may represent the basic mineral unit. For each tablet, it also showed a typical pattern, characterized by the formation of opposite triangular domains of mineral dissolution.

\subsubsection{Minor Elements in Prisms and Nacre}

Beside the shapes of their crystallites and their mineralogy, another aspect that marks the difference between the prismatic and the nacreous layer is their bulk elemental composition obtained by microprobe analysis (Masuda and Hirano 1980; Cuif et al. 1985). Prisms exhibit high levels of magnesium and sulfur, respectively 6,000 and 4,000/4,500 ppm, while the concentrations of these two elements are about $500 \mathrm{ppm}$ in nacre. On the contrary, the concentrations of sodium and of strontium are higher in nacre, respectively $>6,000$ and $1,500 \mathrm{ppm}$, in comparison to prisms (4,500 and less than 1,000 ppm). The case of sulfur is interesting (Cuif et al. 1985, 1986, 1988a): its concentration, measured along the prisms, is constant throughout the prisms length, but drastically collapses at the prisms/nacre transition. Few years ago, FTIR, WDX, and XANES data (Dauphin 2002; Dauphin 2003; Dauphin et al. 2003) showed first that the sulfur in the prisms is present as sulfate, and second, demonstrated that the intracrystalline prism matrix is particularly enriched in sulfated polysaccharides. This corroborated the previous finding of Wada (1980), who underlined the importance of sulfur (under the form of polysaccharides) deposited on a glass coverslip preparation placed in Pinna attenuata.

\subsection{The Shell Matrices of Pinna sp. and of Pinna nobilis}

\subsubsection{Early Biochemical Studies}

The discovery of "conchiolin"- the strongly insoluble organic fraction extracted from nacre - and its subsequent naming by Frémy (1855) was the starting point of the analysis of several insoluble organic fractions associated to diverse molluscan shell microstructures. For almost a century, due to technical limitations, the biochemical information retrieved from shell proteins was circumscribed to that on the composition in their elementary bricks, amino acids. Consequently, most of the studies performed on shell matrices, between the beginning of the twentieth century 
and the late sixties, focused on the amino acid compositions, usually obtained after hydrochloric acid hydrolysis of the matrix (for an old - but rather complete review, see Grégoire 1972).

The first biochemical characterization of the shell matrix of Pinna sp. was performed by Wetzel (1900), who clearly established the proteinaceous nature of "conchiolin," by detecting glycine, leucine, tyrosine, and arginine residues in "conchiolin" hydrolyzates from prisms and nacre. Interestingly, he also showed that the prisms conchiolin, i.e., the substance that composes the interprismatic walls, was different in its amino acid composition from the nacre conchiolin.

Half a century later, Roche et al. (1951) and Ranson (1952, 1966) observed that the "conchiolin" of the calcitic prisms of Pinna sp. had a higher content in Tyr and Gly and lower content in arginine, serine, and glutamic acid residues than the nacre conchiolin. Akiyama (1966) also observed a high amount of glycine in the prismatic matrix of Pinna attenuata.

Amino acid analyses on prisms and nacre "conchiolin" of the pinnid bivalves Pinna nobilis and Atrina nigra were performed by Bricteux-Grégoire et al. (1968). For the nacre of $P$. nobilis, they obtained a composition dominated by alanine (29\%), glycine (21\%), aspartic acid (13\%), then serine (9\%), while, for prisms, glycine $(37 \%)$ and aspartic acid $(23 \%)$ constituted the dominant amino acids. The proportions of amino acid residues varied in the same proportions for A. nigra. Today, we know that the "conchiolin" terminology defines a mixture of different insoluble constituents that include hydrophobic proteins and chitin.

The discovery that molluscan shell matrices comprise also soluble intracrystalline components (Crenshaw 1972) and the emphasis of their role in calcification process (Weiner et Hood 1975) led many investigators in biomineralization to focus on this previously undetected organic fraction: not only was the soluble fraction accessible to amino acid analysis but also to aqueous phase fractionation techniques, such as chromatography or electrophoresis. At that time, the general perspective was to purify single proteins and obtain sequence information.

Nakahara et al. (1980) performed series of amino acid analyses on prismassociated matrices of Pinna carnea, Atrina pectinata, and pearl oysters. They distinguished the interprismatic insoluble walls from an organic fraction that they considered to be intraprismatic. For the first one ( $P$. carnea), they partly confirmed previous findings: enrichment in glycine and aspartic acid. They however found that this matrix was also enriched in tyrosine and cysteine residues, the high amount of tyrosine suggesting that the interprismatic walls were insolubilized by a quinonetanning process. For the intraprismatic matrix, they measured a striking $72 \%$ molar for aspartic acid (62\% in the case of $A$. pectinata), a fact that fully confirmed the previous finding of Weiner and Hood (1975).

Few years later, Cuif et al. (1987b, 1988b, 1991), Frérotte (1987), Kervadec (1990), and Marin (1992) analyzed the soluble matrices from prisms and nacre of Pinna nobilis by gel permeation or ion-exchange chromatography, both fractionation techniques coupled with subsequent amino acid analysis (after $6 \mathrm{~N}-\mathrm{HCL}$ hydrolysis and PITC pre-column derivatization). They clearly evidenced that the two soluble matrices were heterogeneous in their chromatography profiles, a fact 
which was confirmed by the heterogeneity of amino acid compositions of isolated peaks (Marin 1992). Furthermore, Marin (1992) showed that the intraprismatic matrix was much more acidic than the soluble matrix associated to nacre. However, none of the fractionation technique used was able to obtain single macromolecular components that could be sequenced further. The reasons of this failure were that the macromolecules associated to prisms and nacre - and more generally to all calcified tissues - are not globular and that many of them are negatively charged. In addition, they tend to be polydisperse, and are frequently submitted to posttranslational modifications, such as glycosylation or phosphorylation. Consequently, they behave anomalously during chromatographical fractionation (for technical informations on acidic proteins, see the review of Marin and Luquet 2007). These combined technical obstacles precluded for several years the possibility to purify a single protein and to obtain partial or full amino acid sequences.

\subsubsection{Electrophoresis and Serology on the Shell Matrix of Pinna nobilis}

Decisive analytical improvements were brought in biomineralization investigations, by using polyacrylamide gel electrophoresis in denaturing conditions. By extracting acido-soluble matrices from prism and nacre of Pinna nobilis, Marin et al. (1994) showed that the two matrices exhibited similarities and differences: none of them stained accurately with the classical Coomassie Brilliant Blue for the reasons indicated here above; when stained with silver nitrate, the two electrophoretic profiles were different but both were characterized by few discrete macromolecular components (from 10 to above $50 \mathrm{kDa}$ ), embedded in smearing polydisperse macromolecules; in the prisms matrix, one prominent band was observed around $15 \mathrm{kDa}$, and another one, at higher molecular weight; the biggest difference was observed when employing alcian blue for revealing polyanionic substances, such as sulfated sugars: the soluble matrix associated to nacre did not stain at all, whereas the one extracted from prisms gave a strong staining. This clearly suggested that the prism matrix was extremely acidic ("polyanionic"). We correlated this finding with the high content of sulfur of the prisms, this finding being also correlated to the high quantity of soluble sulfated polysaccharides of the intraprismatic matrix.

Another approach, which was also very effective and brought a significant contribution to the analysis of the shell matrices from Pinna nobilis, was serology, also called serotaxonomy. As described elsewhere (Muyzer et al. 1984; Collins et al. 1991; Marin et al. 1999), the method exploits the ability of the mammalian immune system to produce antibodies against foreign macromolecules, e.g., macromolecules extracted from shells. Usually, antibodies recognize short domains, called epitopes (or antigenic determinants), which, in the case of proteins, are not longer than 5-8 amino acid residues. Collected antibodies can be tested against a variety of shell matrices, via different techniques (ELISA, dot blot, Western blots, 
in situ localization), the aim of which is to provide a comparison between matrices. Thus, although the method does not provide any structural information on the studied shell matrices, it gives indirectly an informative picture on the degree of structural similarity between macromolecules.

In the present case, polyclonal antibodies were produced in rabbits against nonfractionated acetic acid-soluble matrix macromolecules extracted from prisms and from nacre of Pinna nobilis. These antibodies were tested against prisms and nacre matrices (Fig. 13.4a for the western blot results obtained with the antibodies raised against prisms matrix). They cross-reacted in a more or less symmetrical way, i.e., antibodies elicited against the nacre matrix recognized, in a lesser extent, epitopes in the prisms matrix, and antibodies elicited against the prisms matrix crossed-reacted with nacre matrix. This suggested that both matrices shared several epitopes. This idea was - and still is - very appealing: it may indicate that shell microstructures as different as prisms and nacre can be produced from different secretory protein repertoires, which contain however some identical epitopes (short domains). It is interesting to notice that before our study, by using a different approach - a combination of ion-exchange and HPLC chromatography on the soluble nacre and prisms matrices of the mussel Mytilus californianus - Weiner (1983) observed that some of the numerous peaks were shared by the two matrices. He consequently came to the conclusion of a partial similarity between the two matrices.

As the developed anti-prism/nacre matrices antibodies exhibited good titers and gave satisfactory results, we tested them by ELISA technique against a broad range of shell matrices extracted from numerous molluscs, including bivalves, gastropods, and cephalopods. In addition, the antibodies were tested against skeletal matrices of extra-group samples, brachiopods, and corals (Marin 1992; Marin et al. 1999, 2007a). The results were surprising (Fig. 13.4b). First, none of the two antibodies gave immunological patterns, which could be simply correlated to mollusc phylogeny. Consequently, these antibodies could not be used for serotaxonomy purposes. To give an example, both antibodies gave strong crossreactivities with the shell matrices of the two gastropods Haliotis and Littorina, while they did not cross-react with the pteriomorphid bivalve Arca (Fig. 13.4). One of the two antibodies (anti-nacre) also reacted strongly with the shell matrix of the cephalopod Nautilus. Second, the obtained signals were not strictly correlated to shell microstructures, neither to the mineralogy (calcite vs. aragonite). For the antiprisms antiserum, we observed that it strongly cross-reacted with the matrices of nacro-prismatic pteriomorphid bivalves (Mytilus, Pteria, Pteria, Isognomon, Brachidontes), with those of foliated pteriomorphids (Pecten, Crassostrea) but also with the fully aragonitic nacro-prismatic paleoheterodont bivalves (Unio, Anodonta, Neotrigonia). There were no cross-reactivities with the matrices of "crossed-lamellar" aragonitic veneroids (Venus, Mercenaria, Tridacna, Ensis), but curiously, cross-reactivities with aragonitic crossed-lamellar myoids (Mya, Pholas). This pattern was not expressed with the second antibody (anti-nacre). Of course, we were fully aware that the serological approach has some drawbacks: (a) it did not give any indication on the chemical nature of the target antigens; (b) 

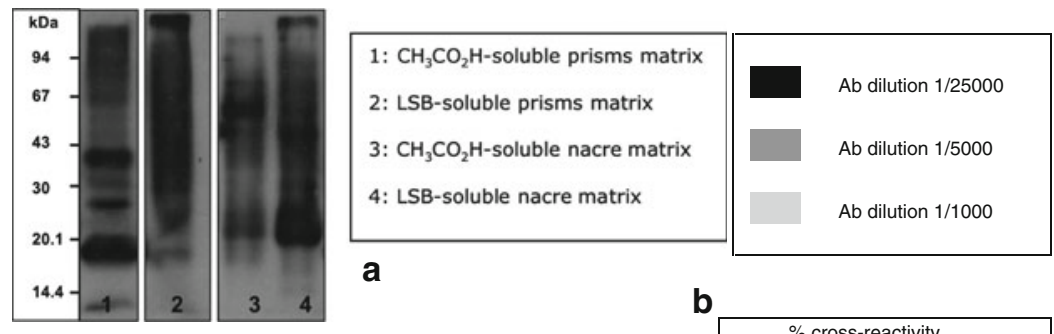

a

\begin{tabular}{|c|c|c|c|c|c|c|}
\hline 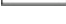 & & & & & & $\%$ cross-reactivity \\
\hline Phyl. & Cl. & Sub-class & Order & Genus & Min. & 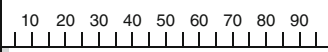 \\
\hline & & Paleotax odonta & Nuculoida & Nucula & A & \\
\hline & & & Arcoida & Arca & A & \\
\hline & & & & Glycymeris & A & \\
\hline & & & & Mytilus prisms & C & \\
\hline & & & Mytiloida & Mytilus nacre & A & \\
\hline & $B$ & & & Brachidontes & A & \\
\hline & & Pteriomorphia & Pinnoida & Pinna prisms & C & \\
\hline & I & & & Pinna nacre & $\mathrm{A}$ & \\
\hline & & & Pterioida & Pteria & $\mathrm{C}+\mathrm{A}$ & \\
\hline M & $V$ & & & Isognomon & $\mathrm{C}+\mathrm{A}$ & \\
\hline & & & & Pecten & $C$ & \\
\hline 0 & $A$ & & Pectinoida & Chlamys & $\mathrm{C}+\mathrm{A}$ & \\
\hline & & & & Spondylus & $\mathrm{C}+\mathrm{A}$ & \\
\hline $\mathbf{L}$ & $L$ & & Ostreoida & Crassostrea & $\mathrm{C}$ & \\
\hline & & & Unionoida & Anodonta & $A$ & \\
\hline L & $\boldsymbol{V}$ & Paleoheterodonta & & Unio & A & \\
\hline & & & Trigonioida & Neotrigonia & $A$ & \\
\hline U & I & & & Lucina & $A$ & \\
\hline & & & & Crassatella & A & \\
\hline S & $A$ & & & Cardium & A & \\
\hline & & & & Tridacna & A & \\
\hline C & & & & Mactra & A & \\
\hline & & & Veneroida & Lutraria & A & \\
\hline A & & Heterodonta & & Corbicula & A & \\
\hline & & & & Ensis & A & \\
\hline & & & & Venus & A & \\
\hline & & & & Meretrix & A & \\
\hline & & & & Mercenaria & A & \\
\hline & & & & Dosinia & A & \\
\hline & & & & Ruditapes & A & \\
\hline & & & Myoida & Mya & A & \\
\hline & & & & Pholas & $\mathrm{A}$ & \\
\hline & & & Vetigastropoda & Haliotis & $\mathrm{C}+\mathrm{A}$ & \\
\hline & GAS & STROPODA & & Trochus & $\mathrm{C}+\mathrm{A}$ & \\
\hline & & & Caenogastropoda & Littorina & $A$ & \\
\hline & & & & Strombus & A & \\
\hline & $\overline{C E P}$ & HALOPODA & Nautiloida & Nautilus & $\mathrm{A}$ & \\
\hline & & & Coleoida & Argonauta & $\mathrm{A}$ & \\
\hline & & & & Coptothyris & C & \\
\hline BRAC & SHIOF & PODA & Terebratulida & Laqueus & C & \\
\hline & & & & Terebratella & $\mathrm{C}$ & \\
\hline & & & & Acropora & A & \\
\hline CNID & ARIA & & Scleractinia & Galaxea & A & \\
\hline & & & & Merulina & A & \\
\hline
\end{tabular}

Fig. 13.4 Cross-reactivities of the soluble skeletal matrices of several invertebrates with a polyclonal antibody elicited against the acetic acid-soluble matrix of the prismatic layer 
widely different epitopes could be recognized at a similar level by a given antibody; (c) because antibodies were raised against protein mixtures, some of which were immunogenic, some of which not, the final signal may have been contorted and biased. In spite of these limitations, the immunological pattern obtained suggested, on one hand, that the secretory repertoire used by different phylogenetically distant molluscs could exhibit some similarities; On the other hand, some secretory repertoires appeared to be extremely different from group to group, the best illustration being the clear gap between pteriomorphids and heterodonts bivalves.

\subsubsection{Molecular Data on the Shell of P. nobilis}

Although the serological approach gave indications on the overall homologies of matrices in comparison to that of $P$. nobilis, sequence information on the macromolecular constituents of the prisms and nacre matrices were still badly missing. This gap in the knowledge started to be filled by finding tricks to accurately purify proteins directly from shell extracts, and, as an alternative approach, by using molecular biology techniques to fish out randomly transcripts encoding shell proteins. The first approach gave us two proteins, caspartin and calprismin, while the second one, mucoperlin (Marin et al. 2003b; Marin and Luquet 2005). The first two proteins belong to the group of highly acidic shell proteins (Fig. 13.5), while the third one, which is moderately acidic, appears to belong to a completely different protein family (Fig. 13.6). In addition, new proteins of the shell of $P$. nobilis are now being discovered in our lab by one of us (P. Narayanappa).

\subsubsection{Molecular Data on the Prisms}

The way two prism matrix proteins were isolated relies on the following observation: first, most of the shell matrices proteins have a low content of amino acids that contain aromatic groups (tyrosine, tryptophane, phenylalanine). This implies that they cannot be easily detected with the classical spectrophotometric methods at $280 \mathrm{~nm}$. Second, in our numerous attempts to visualize proteins in a monodimensional gel, we often obtained sharper pictures on Western blots when the blot

Fig. 13.4 (continued) of $P$. nobilis. (a) western blot of the different shell matrices of $P$. nobilis (prisms, lanes 1 and 2; nacre, lanes 3 and 4) with this antibody. (b) Cross-reactivities measured with ELISA. Although the highest cross-reactivities are recorded with nacro-prismatic pteriomorphid bivalves, the obtained signal cannot be considered to be "taxonomic": some distantly related genera (Haliotis, Littorina) cross-react strongly. The signal is neither "microstructural": some genera with shell microstructures that are different from the nacroprismatic microstructure of $P$. nobilis (Glycymeris, Pecten) also give high cross-reactivities. Except Ruditapes, none of the veneroid bivalves cross-react. Similarly, none of the tested extragroups (cnidarian, brachiopod) give cross-reactivity. Min mineralogy, $A$ aragonite, $C$ calcite 

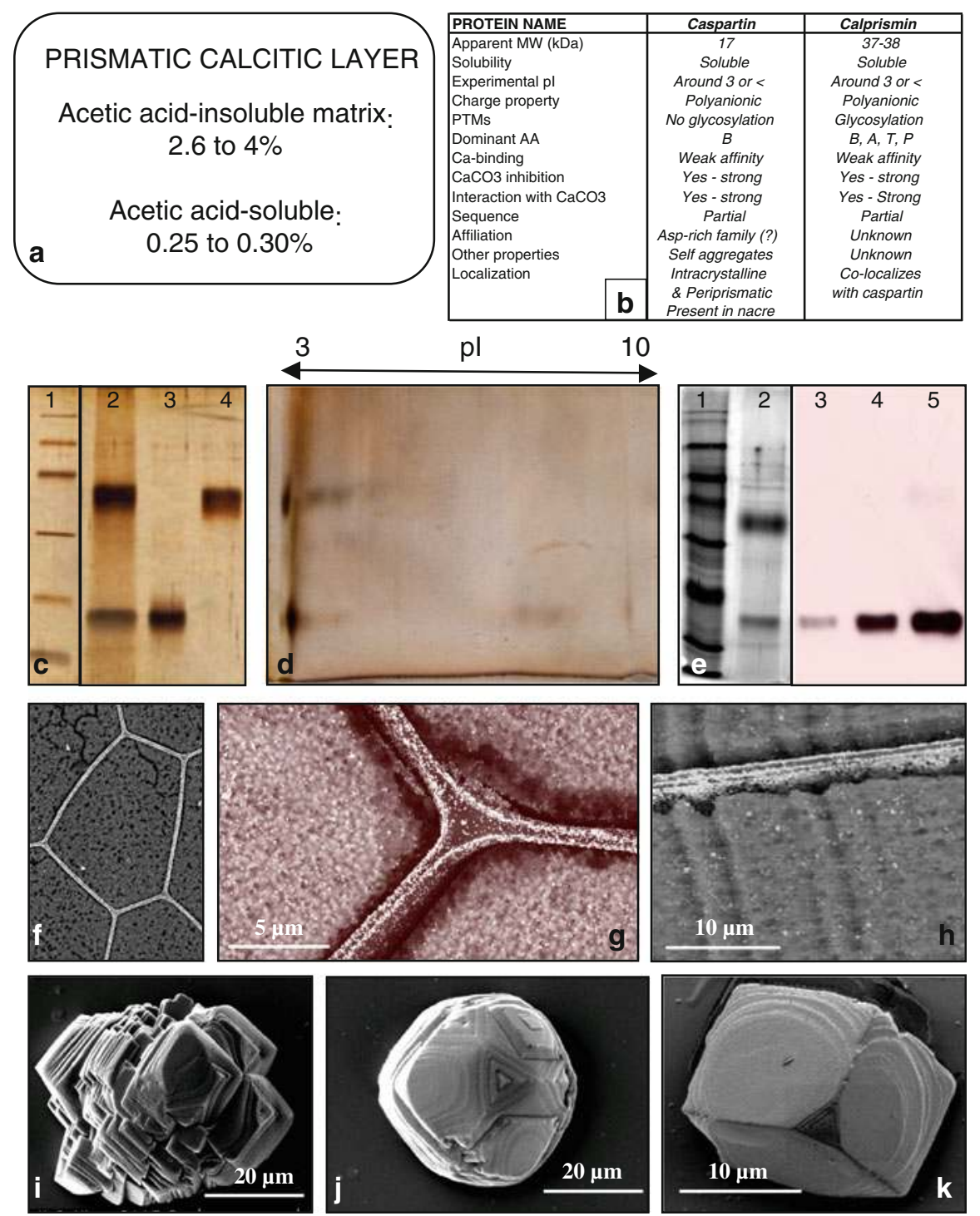

Fig. 13.5 The calcifying matrix of the shell prismatic layer of Pinna nobilis. (a) Proportions of soluble and insoluble matrices. (b) Summary of the biochemical properties of caspartin and calprismin; B is the one-letter symbol for Asx, i.e., Asp or Asn. (c) SDS-PAGE of the intracrystalline prisms matrix and isolated fractions; lane 1, molecular weight markers, from top to bottom 94, 67, 43, 30, 20, and $14.4 \mathrm{kDa}$; lane 2, acetic acid-soluble matrix of isolated prisms; lane 3, purified caspartin; lane 4, purified calprismin. (d) 2D-gel electrophoresis of the acetic acidsoluble matrix of isolated prisms. (e) Western blot of the acetic acid-soluble matrix of isolated prisms. The blotted extract was incubated with the polyclonal antibody (dilution 1:3,000) raised against the purified caspartin; lane 1, molecular weight markers, from top to bottom 116, 97, 66, $45,31,21.5,14.4$ and $6.5 \mathrm{kDa}$; lane 2, acetic acid-soluble matrix of isolated prisms, silver stained; lanes 3-5, western blot of the acetic acid-soluble matrix of isolated prisms, $5 \mu \mathrm{g}$ (lane 3), $10 \mu \mathrm{g}$ 
was priorly incubated with antibodies raised against the non-fractionated matrix than by using silver nitrate or Coomassie Blue staining on the gel. For unknown reasons, it seems that discrete components of the matrix are more immunogenic than smearing macromolecules, which results in the improvement of the signal/ background ratio (if we consider that the smearing materials are part of the "background effect"). We used this property to isolate two prominent prism matrix proteins as follows: after the isolation of single prisms with dilute sodium hypochlorite, the intraprismatic matrix was extracted by dilute cold acetic acid, according to our standard procedure (Marin et al. 2001). Then, the matrix was fractionated by preparative electrophoresis, which allowed the "blind" collection of numerous fractions. Each fraction was blotted on a PVDF membrane by dot-blot apparatus, and the membrane was subsequently treated with anti-prisms or antinacre matrix antibodies, according to a classical procedure used in Western blot. This allowed detecting in which fractions were eluted the proteins of interest. Proteins were collected, and extensively dialyzed before being freeze-dried. The technique was described in Marin et al. (2001) and in Marin (2003).

In this manner, we identified two new proteins, that we subsequently named caspartin and calprismin, respectively (Marin and Luquet 2005; Marin et al. 2005). Calprismin is an acidic intracrystalline soluble protein of $38 \mathrm{kDa}$ of apparent molecular weight. It is enriched in Ala, Asx, Thr, and Pro residues, these four residues constituting $55 \%$ of the sequence. The N-terminus of calprismin (61 a residues, about $18 \%$ of the sequence) was sequenced. It is enriched in Glu residues and presents a pattern containing four cysteine residues that is also observed in different extracellular matrix (ECM) proteins. A blast search did not allow finding affiliation of calprismin with other shell proteins, neither with other ECM proteins. Calprismin is a very weak calcium-binding protein, and this property is extremely labile. On 2D-gel, calprismin migrates as a thick spot that is localized below $p I 3$. Two other diffuse spots, which are slightly less acidic, suggest that calprismin may have different isoforms/glycoforms. The enzymatic deglycosylation of calprismin with a cocktail of endoglycosidases led to a loss of few $\mathrm{kDa}$ of apparent molecular weight on a gel. This weight loss is correlated with the disappearance of Alcian blue staining of the protein after deglycosylation. Calprismin may be rather unstable since it degrades when performing a chemical deglycosylation with TFMS acid. The analysis of its N-terminal sequence, and the comparison with other N/Cterminal sequences of prisms-associated proteins allowed obtaining general features (Evans 2008): abundance of anionic residues, low amount of cationic residues, variable amounts of hydrogen-bonding donor/acceptor (HBDA). Like other proteins associated to prisms, calprismin may be intrinsically disordered,

Fig. 13.5 (continued) (lane 4), $20 \mu \mathrm{g}$ (lane 5). (f-h) Immunogold localization of caspartin. (f) cross section, low magnification. (g) cross section, high magnification of a triple junction. (h) longitudinal section of a prism. (i-k) in vitro $\mathrm{CaCO}_{3}$ crystallization experiment in the presence of purified caspartin. (i,j) polycrystalline aggregates formed at $2 \mu \mathrm{g} / \mathrm{ml}$ of caspartin. (k) "single" crystal formed at $3 \mu \mathrm{g} / \mathrm{ml}$ of caspartin 


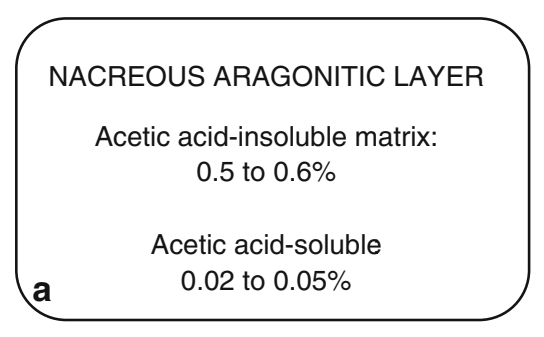

\begin{tabular}{|c|c|}
\hline $\begin{array}{l}\text { PROTEIN NAME } \\
\end{array}$ & Mucoperlin \\
\hline Apparent MW (kDa) & 67 \\
\hline Solubility & Soluble \\
\hline Theoretical pI & 4.9 \\
\hline PTMs & Glycosylations (O-type) \\
\hline Dominant AA & $S, P$ \\
\hline Ca-binding & Weak affinity \\
\hline Other properties & May polymerize (?) \\
\hline \multirow{3}{*}{ Primary structure } & $\begin{array}{l}\text { a) Short N-terminus: } 11 \text { aa } \\
\text { b) } 13 \text { tandem repeats of } 31 \text { aa, rich }\end{array}$ \\
\hline & in $S$ and $P: 403$ aa \\
\hline & $\begin{array}{c}\text { c) C-terminus: acidic \& hydrophobic, } \\
3 \mathrm{C} \text { in the last } 41 \mathrm{aa}\end{array}$ \\
\hline Protein family & Mucin-type \\
\hline \multirow[t]{2}{*}{ Localization } & Intertabular \\
\hline & Specific of the nacreous layer \\
\hline
\end{tabular}
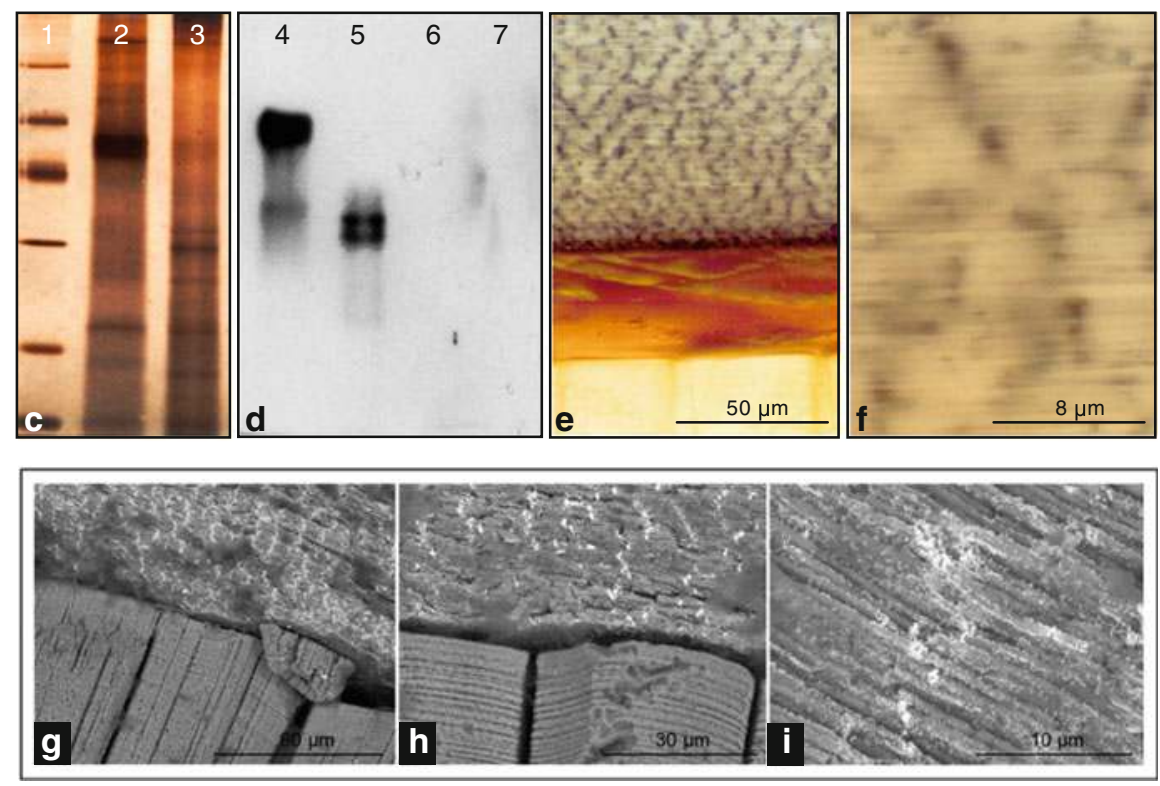

Fig. 13.6 The calcifying matrix of the shell nacreous layer of Pinna nobilis. (a) Proportions of soluble and insoluble matrices. (b) Summary of the biochemical properties of mucoperlin, an acidic nacre-specific protein. (c) SDS-PAGE of the acetic acid-soluble (lane 2) and of the acetic acid-insoluble/Laemmli-soluble (lane 3) nacre extracts. Mucoperlin is the thick band in lane 2. (d) western blot of the different shell matrices of $P$. nobilis. The blot was incubated with a polyclonal antibody elicited against doubly purified recombinant mucoperlin; lane 4, acetic acid-soluble nacre extract; lane 5, acetic acid-insoluble/Laemmli-soluble nacre extract; lane 6, acetic acid-soluble prisms extract; lane 7, acetic acid-insoluble/Laemmli-soluble prisms extract. There is no signal in the prisms extracts, indicating that mucoperlin is nacre specific. (e, f) immunolocalization of mucoperlin in cross sections of nacro-prismatic preparations, observation with an optical microscope; (e) lower part, prisms, upper part, nacre. (f) nacre, at higher magnification. (g-i) immunogold staining of a cross section (fresh fracture), observed with a SEM. (i) the white spots, which localize mucoperlin, are situated between nacre tablets (intertabular location). Patterns in $(\mathbf{e}, \mathbf{f})$ and in $(\mathbf{g}-\mathbf{i})$ are identical

and may require external interactions to stabilize its secondary structure (Evans 2008). One of us (P. Narayanappa) works on obtaining the full sequence of calprismin to confirm this prediction. Other ongoing characterizations include the 
effect of calprismin in vitro, its localization in the shell by immunogold, and its expression in mantle tissues.

The second protein, caspartin, has been studied in vitro more in detail (Fig. 13.5), although its sequence is still far from being complete (Marin et al. 2005, 2007a, b). Similarly to calprismin, caspartin is an intracrystalline acidic protein, which is abundant in the acid-soluble extract of the prisms. Caspartin has a molecular weight of about $17 \mathrm{kDa}$. It is extremely enriched in aspartate residues (more than 60\%). Caspartin exhibits better calcium-binding ability than calprismin, but its affinity for calcium is also weak, i.e., the fixation of calcium is reversible, and calcium can be easily removed by gentle rinsing of the membrane where caspartin has been blotted. Caspartin does not seem to be glycosylated, but we do not exclude the possibility that it may be phosphorylated. An interesting finding was that caspartin self-agregates in solution: in non-denaturing gels, we were able to show that caspartin forms di-, tri-, tetra-, penta-, hexa-, and heptamers. On 2D gels, caspartin migrates as a big spot at $p$ I below 3 . However, three tenuous minor spots of the same molecular weight, one in the acidic domain, and two, basic, are also observed, which may indicate that caspartin may not be absolutely pure, or that it exhibits isoforms. In vitro, caspartin is a powerful inhibitor of the precipitation of calcium carbonate, since it induces an inhibitory effect for concentrations inferior to $1 \mu \mathrm{g} / \mathrm{ml}$. Caspartin has also drastic effects on the morphology of calcite crystals grown in vitro: effects are already observed around $0.2 \mu \mathrm{g} / \mathrm{ml}$, and they increase with the concentration of the protein in solution. Between 1 and $3 \mu \mathrm{g} / \mathrm{ml}$, caspartin induces the formation of polycrystalline aggregates, together with the formation of "single crystals," which exhibit a foliation. When the concentration of caspartin is increased, the size of the crystals decreases, and above a threshold, caspartin acts as an inhibitor of calcification and no crystals are produced. A polyclonal antibody, specific of caspartin, indicated that caspartin, or a similar $17-\mathrm{kDa}$ protein, is also present in the nacreous layer of Pinna nobilis, but in much lesser amounts (6-8 times less). This antibody was used to localize caspartin directly in the shell of Pinna nobilis (Marin et al. 2007b). In cross sections, perpendicular to the prisms axis, we observe that caspartin has two locations: first, it is distributed at the surface of the prisms (= within the prisms), a predictable finding. We do not observe a particular pattern, but rather, a uniform distribution of the signal at the prisms surface. Second, more surprisingly, caspartin occupies also an intercristalline location: it forms a continuous film at the interface between the prisms themselves and the interprismatic insoluble walls. In other words, the insoluble hydrophobic interprismatic wall is sandwiched between two caspartin-containing layers. In longitudinal sections, caspartin is located discontinuously along the prisms. Its distribution in that dimension is not strictly correlated with the growth lines observed for each prism, although we observed that caspartin may be more concentrated on some growth plans (Marin et al. 2007b).

Following the first biochemical characterization of caspartin (Marin et al. 2005), de novo sequencing of caspartin extracts was performed and different short peptides were obtained, by using trypsin, pepsin, or AspN digests (Marin et al. 2007b). However, so far, by using different couples of degenerated oligo primers, we did 
not retrieve yet the full sequence of caspartin, and more work has still to be done before we elucidate its complete primary structure.

\subsubsection{Molecular Data on the Nacre}

The second strategy we chose was to construct a cDNA library from mantle tissues of non-stressed juvenile specimens of Pinna nobilis, which were actively calcifying. Briefly, the technique implies the extraction of total RNAs from a tissue, the purification of the messenger RNAs by Oligo-dT resin, the conversion of the transcripts into double-stranded cDNAs, the cloning of "adaptors" in the two termini of the cDNAs, the selection of the longest cDNA by size-exclusion chromatography, the cloning of the cDNAs into a phage vector, and the packaging of the construct into phage capsids. The resulting primary library, which yielded about $3.5 \times 10^{5}$ clones, was amplified once.

At that point, because we did not have sequence information on shell proteins of Pinna nobilis - let us recall that the first full sequence of a shell protein from the pearl oyster Pinctada was published at the end of 1996 - we could not develop degenerate probes (biotin or digoxigenin-labeled) for screening the constructed library. As our constructed cDNA library was an expression library, we chose to screen it with "our" homologous antibodies that we used before, those elicited against the acid-soluble shell matrices of prisms and of nacre of Pinna nobilis.

This operation described elsewhere (Marin et al. 2000, 2003a) generated series of clones, which were re-screened twice (secondary and tertiary screening) to purity. The pure clones exhibited long cDNA inserts (above $2 \mathrm{~kb}$ ), which encoded a putative protein of 636 amino acids. The analysis of this ORF showed that the corresponding acidic protein (theoretical $\mathrm{pI}=4.9$ ) possesses three domains: a short $\mathrm{N}$-terminus, then a long central domain constituted of a succession of 13 almost identical repeats put in tandem (403 residues in total), which represents two-third of the protein, then a C-terminus (222 residues). Each tandem repeat, 31 amino acids long, is enriched in proline and serine residues, and many of these serine residues are presumably glycosylated. Although similarity search indicated only limited homologies with known proteins, the most convincing hit was found with PGM, a pig gastric mucin. Similarities with a mucin may not be fortuitous. Indeed, our protein possesses at least two properties found in mucins, the main protein components found in mucus secretions: the presence of tandem repeats, and the richness of these repeats in proline and serine residues. In addition, like most of the mucins, our protein exhibits, in the C-terminus, few cysteine residues. In mucins, these residues potentially allow the formation of dimers first, and then, of multimeric insoluble gels. Because of these features, we consequently chose to name this protein mucoperlin (Fig. 13.6).

Mucoperlin was overexpressed in a bacterial strain, and after a double purification, the single obtained band was used for generating a very specific polyclonal antibody (Marin et al. 2000, 2003a) and for different in vitro experiments. Because the overexpressed mucoperlin did not exhibit posttranslational modifications, it was not active in "inhibition tests" e.g., neither in calcium-binding assay. The antibody 
elicited against the recombinant mucoperlin reacted only with nacre extracts, but not at all with prisms extracts, on Western blots, on dot blots or on ELISA (Fig. 13.6d). This clearly suggested that mucoperlin is specific of the nacreous layer of Pinna nobilis. To our knowledge, this was the first convincing demonstration of the existence of a nacre-specific protein among molluscs. Our finding was confirmed by screening mucoperlin clones with anti-prisms matrix and anti-nacre matrix antibodies, separately (Marin et al. 2003a), and by histological staining: using conventional staining of shell cross sections, we showed that mucoperlin was localized in the nacre layer exclusively, and that it was particularly concentrated in the intertabular zones, i.e., the short lateral sides of the tablets, also defined as the zone that is comprised between adjacent tablets (Fig. 13.6e, f). In addition, a staining was also observed in the interlamellar matrix, but this staining was much weaker. Later, we repeated the immunohistological experiments by using the more precise immunogold technique (Marin et al. 2007b). We then observed a completely superimposed staining pattern, a concentration of white spots localizing mucoperlin in the intertabular zones (F. Marin, unpublished data, 2006; Fig. 13.6g-i; Marin 2009).

The identification and molecular characterization of mucoperlin, an acidic mucin-like protein, in a shell was a "première" and established a bridge between molecular physiology, especially that of vertebrates, and biomineralization in general. Mucins are indeed involved in several functions, such as lubrication, protection of epithelial tissues against chemical or microbial aggressors. They are also involved in cell signaling (Bafna et al. 2008). Interestingly, in vertebrates, mucins are also associated with fluids that calcify or that prevent calcification. In the buccal cavity, the saliva is a supersaturated fluid, which - fortunately for us - never calcifies. The main reason is that saliva contains a cortege of proteins that prevent the deposition of calcium salts. Salivary mucins, when free in solution, do not allow calcium salts crystals to grow further (Tabak et al. 1985; Nieuw-Amerongen et al. 1989; Tabak 1995). Furthermore, these mucins can adhere on tooth hydroxyapatite with a strong affinity, and prevent their demineralization (Meyer-Lueckel et al. 2006). Similarly, in the bladder, urine comprises a set of proteins, among which the Tamm-Horsfall Protein (THP) and urinary mucins, the function of which is to prevent the precipitation of calcium oxalates or of uric acid (Grases and Llobera 1998). Finally, the gallbladder is also an organ in contact with supersaturated fluids (Afdhal et al. 1995). In pathological situations (lithiasis), gallbladder mucins are frequently involved in the deposition of mineralized concretions (Lechene de la Porte et al. 1996), an observation which suggests that they may be also involved in nucleation processes. Clearly, mucins in general seem to play important although probably underestimated - functions associated with calcification.

\subsubsection{Other Shell Proteins of $P$. nobilis}

Although caspartin and calprismin represent the two dominant intracrystalline proteins of the isolated prisms of $P$. nobilis, we detected about eight minor protein 
bands in the acetic acid-soluble prisms extract, below $10 \mathrm{kDa}$, and above $60 \mathrm{kDa}$, on 1D electrophoretic profiles (Marin et al. 2007b). However, sequence information on these bands is missing, so far. When the matrix of the complete prismatic layer - and not only the sodium hypochlorite-isolated prisms - is extracted (P. Narayanappa, unpublished, 2010), a huge set of additional protein bands are visualized on gel, probably comprising proteins which are weakly linked to the mineral phase. Similarly, in the nacre extracts, several proteins bands have been detected in the acetic acid-soluble and in the Laemmli-soluble fractions (Marin et al. 2000). For none of these proteins, we possess sequence information.

Other putative shell proteins have been retrieved by one of us (P. Narayanappa un published, 2010) by screening our cDNA expression library of the mantle of $P$. nobilis with anti-caspartin and anti-calprismin polyclonal antibodies. This operation yielded additional clones encoding putative proteins that have a "shell" signature: short hydrophobic or acidic motifs, predominance of few amino acids, such as glutamic acid, serine or leucine in the overall composition of the protein. Among them, the translated product of clone CLP2T7 is enriched in glutamic acid (18\%), in leucine $(10 \%)$, and in serine $(10.3 \%)$, while the one of clone CSP3 is characterized by an extremely acidic C-terminus (with a poly-D domain). Interestingly, in parallel to the immunoscreening, a proteomic analysis of the acetic acid-soluble prisms matrix of $P$. nobilis yielded different peptides. One of them belongs to CSP3 translated sequence (Narayanappa et al., in preparation), proving that this putative protein is truly a shell matrix protein of the prismatic layer. Our results are being compiled for their subsequent publication.

\subsubsection{Effect of the Acidic Proteins of P. nobilis on "Calcification," Sensu Lato}

\subsubsection{1 “Classical” Biochemical Effects}

As described in Sect. 4.3, the identified shell proteins of $P$. nobilis exert different biochemical effects in relation with calcification. These effects, such as the calcium-binding effect, the inhibition effect, or the interference with $\mathrm{CaCO}_{3}$ crystallization, can be quantified in a "test tube." Although they give us precious information on the putative functions of the tested protein, we are fully aware that, by no means, they substitute to the "function." In the present paragraph, we clearly dissociate the effects - which are known - from the true functions - which are still elusive.

The calcium-binding property of the shell proteins of $P$. nobilis is an interesting property, prone to discussion. In our hands, we always observed that the calciumbinding ability of caspartin, of calprismin, and of the nacre and prisms matrices in general, was labile. We observed that the level of calcium-binding was better for the whole matrices than for its separate constituents, like caspartin or calprismin, when 
equivalent amounts of materials were tested. We suggested that these two proteins, and probably many more proteins of the prisms and nacre matrices, belong to the class of low affinity-high capacity calcium-binding proteins (Maurer et al. 1996; Marin and Luquet 2007). The binding of calcium ions would be performed via the negatively charged side chains of aspartate and glutamate residues, and maybe via some of their posttranslational modifications, many of which may exhibit anionic properties: glycosylations, in particular those involving sulfated sugars, and phosphorylation of serine and threonine residues. Although the full sequences of caspartin and of calprismin are not known, it is very likely that these proteins do not exhibit canonical calcium-binding domains, such as EF-hands (Kretsinger 1976), which are characteristic of the class of low capacity-high affinity calciumbinding protein. For a shell protein, we believe that binding reversibly numerous calcium ions is probably more compatible with a crystal synthesis process than sequestering strongly few calcium ions. We do not exclude the possibility that bound calcium ions also stabilize shell proteins in vivo and help them to maintain a precise conformation.

The in vitro inhibition property is another point in case. In our hands, we always observed that the acetic acid-soluble matrices of prisms and nacre of $P$. nobilis had good inhibitory effect. However, we observed that the inhibitory effect of the prisms matrix (and of caspartin and calprismin) was much higher than that of nacre matrix, for similar tested concentrations (Marin 1992). This effect seems to be correlated with the "acidity" of both matrices, the prisms matrix being much more "acidic" than the nacre matrix. The higher acidity of proteins associated to calcitic prisms is supported by two observations: first, we have shown in a previous review paper (Marin et al. 2008) that molluscan shell proteins associated to calcite (foliated or prismatic) and the ones associated to aragonite (mainly nacre) exhibit different distributions, when plotted on a diagram showing their theoretical calculated $p$ I vs. their molecular weight. The first ones have a bimodal distribution, either very acidic, either very basic, while the second ones are characterized by weakly acidic to weakly basic $p$ Is. As the very basic proteins of the prisms may be associated to the insoluble framework, the soluble prism matrix proteins are necessarily extremely acidic. Second, anionic posttranslational modifications, such as sulfated sugars, are present in high quantity in the prisms of $P$. nobilis but are almost absent from the nacre matrix proteins. In the case of $P$. nobilis, these two combined factors explain the difference of inhibitory effect of the prisms and the nacre matrices.

At last, proteins of the shell matrix of $P$. nobilis interfere with the precipitation of calcium carbonate in vitro. This effect is dose dependent, up to a certain threshold above which no crystals are formed due to inhibitory effects (Marin et al. 2005). Among the most common crystal figures, one can see the formation of polycrystalline aggregates of calcite and the formation of apparent "single" crystals, which exhibit a layering and truncated corners. Although these effects can be observed with several shell proteins in general, we notice that they are particularly drastic when acidic proteins such as caspartin and calprismin are employed. 


\subsubsection{2 “Nonclassical Effects" of Acidic Proteins of P. nobilis: Effects at the Crystal Lattice Level}

Besides these effects, which can be measured at the micrometric scale (interference tests), or at the macroscopic levels on gels (calcium-binding) or with an electrode (inhibition), far less classical effects have been recorded few years ago. These remarkable findings, which have been generated by our colleagues B. Pokroy and E. Zolotoyabko, both from the Technion in Haifa, Israel, require high-precision diffraction equipment, such as the one of the ESRF, in Grenoble. The goal of their study was to evidence or not whether intracrystalline proteins had an effect on the crystallographic properties of biogenic calcite.

In a first set of experiments, Pokroy and Zolotoyabko measured the lattice parameters of five calcitic molluscan shells microstructures, namely, Pinna nobilis (prisms), Atrina rigida (prisms), Ostrea edulis (foliated), Crassostrea gigas (foliated), and Haliotis rufescens (prisms). By applying corrections dues to the incorporation of magnesium and of sulfur in the crystalline lattice, they calculated the theoretical a, b, c, parameters of these biogenic calcitic crystals. Without any exception, they observed higher lattice parameter values than that of chemical calcite. This clearly suggests a slight distortion of the crystal lattice, the maximal distorsion being according to the $\mathrm{c}$ axis $(0.2 \%)$.

In a second set of experiments, they heated the biogenic calcitic structures, in order to burn the intracrystalline matrix. They observed a relaxation of the crystal lattice, i.e., a reduction of the crystal lattice parameters. This indirectly proved that the intracrystalline molecules induce the lattice distorsion.

To demonstrate without any ambiguity the effect of intracrystalline proteins on calcite, Pokroy crystallized in vitro pure calcite and also calcite in the presence of caspartin, via the ammonium bicarbonate diffusion technique. A comparison of the lattice parameters of both calcites shows again a slight distorsion for the calcite grown with caspartin. These remarkable results were published in 2006 (Pokroy et al. 2006). Recently, Zolotoyabko et al. (2010), by using high-resolution neutron powder diffraction, demonstrated that some of the atomic bonds of biogenic calcite have significantly different lengths as compared to those of geological calcite. Of course, in their measurements, they took in account the incorporation of magnesium ions in the calcite crystal lattice.

Not less remarkable was the following finding of Pokroy and Zolotoyabko. This time they focused on the phenomenon of twinning. In crystallography, twinning is a well-known phenomenon. It is the oriented association of two or more crystals of the same chemical nature. These crystals are linked together via a symmetry operation, according to a plan (twinning plan, twinning by reflection), to an axis (twinning axis, twinning by rotation), or to a center (twinning center, twinning by inversion). In more than 150 years of research in crystallography, the different twinning patterns of calcite had been identified. They are four, corresponding to the following twinning plans: (001), (012), (104), (018). 
By crystallizing in vitro calcite in the presence of caspartin, Pokroy performed X-ray diffraction measurements on the produced crystals. He evidenced a fifth twinning plan, according to (108), which had never been observed before. The results, which were published one year after the first one (Pokroy et al. 2007), have passed largely unnoticed.

So far, it is difficult to measure the impact of such discoveries and their future potential applications for nanotechnology and nanomaterials science. However, from what has been described here above, it becomes clear that biocrystals, such as the calcitic prisms of Pinna nobilis cannot be simply envisaged as "standard chemical crystals with a little bit of organics around."

\subsection{Putative Functions of $P$. nobilis Shell Proteins: Toward a Dynamic View of the Shell Fabrication}

It would appear extremely ambitious - not to say risky - to explain how the prismatic and nacreous layers of Pinna nobilis are formed, only with the $a$ posteriori knowledge of the ultrastructure of these layers, once formed, and only with an extremely limited set of identified proteins. Indeed, for evident technical reasons, there is no continuous record of the calcification process neither in $P$. nobilis, neither in any other type of mollusc and we are limited to sample shells at different growth stages and to check how they look like. Furthermore, we should keep in mind that for a well-studied model, the pearl oyster Pinctada, more than two dozens of shell proteins have been described so far (Marin et al. 2008), but this is simply not sufficient to understand the emergence of calcitic prisms and brickwall nacre of Pinctada shell. We do not have yet the key for understanding what happens at the supramolecular level, and how shell matrix proteins interact with each other. Worse, the transcriptomic analysis performed by Jackson and coworkers on the abalone Haliotis asinina clearly suggests that the elaboration of the molluscan shell microstructures requires some additional protein constituents that are not incorporated in the shell during its growth (Jackson et al. 2006), and consequently, do not belong to the shell matrix. These "silent" proteins may be extremely important contributors to the shell fabrication but they are completely ignored until now. In the case of Pinna nobilis, we do not have the slightest idea of what these proteins could be, and only a transcriptomic approach (ESTs), performed on actively calcifying mantle tissues, will tell us more about the complete cortege of proteins required for shell formation.

In the absence of a complete theory on the mineralization of the molluscan shell, we can only propose hypotheses that take in account geometrical, crystallographic, and physiological constraints, as well as the biochemical properties of the secreted matrices. 


\subsubsection{The Prismatic Layer}

As we have seen in Sect. 3.4, the prisms of Pinna nobilis have a paradoxical status: on one side, they behave like monocrystals, having a single extinction under polarized, analyzed light and a single crystal diffraction pattern; on the other side, they are complex biominerals that exhibit a structural hierarchy. The basic elements are mineral nanograins, which are spatially extremely well oriented, and which form, together with intracrystalline protein an intimate organo-mineral association. A great part of these two contradicting views disappears when considering the formation of calcitic prisms of $P$. nobilis via a "mesocrystal" pathway.

The concept of "mesocrystal" was introduced by Cölfen and Antonietti (2005) and by Cölfen (2007). The formation of mesocrystals typically follows a "nonclassical"crystallization pathway. In short, the starting point is identical to that of classical chemical crystallization pathway, ions, which, by concentration, form nucleation clusters. In natural environments, these clusters can grow or disintegrate again. When they grow, they can reach the size of the critical crystal nucleus. In the case of nonclassical crystallization pathways, the formed primary nanoparticles are temporarily stabilized by organic polymers, which adsorb on their faces. The later stage implies that the nanoparticles, on which organic polymers are adsorbed, assemble and orient in a superstructure, a mesocrystal, which, by fusion of its oriented nanoparticles, becomes a "single" crystal. The polymers associated to this "crystal" remain entrapped after the fusion. When applied to the calcitic prisms of $P$. nobilis, the concept of mesocrystal conciliates the apparent simplicity of each prism with their truly ultrastructural complexity.

How are the calcitic prisms of $P$. nobilis formed? In natural environments, prismatic crystalline structures can be produced through a completely abiotic pathway, which has been described for a long time. Grigor'ev (1965) explained the growth of prismatic structures via a process of competition for space. On an uneven surface, spherulites can be more or less regularly seeded; when they grow in a centrifugal manner, they enter into contact with neighbor spherulites, and consequently compete for space. They tend to grow in one direction, the fast-growing spherulites "absorbing" the slow-growing ones. After a while, the growth of the elongated structures is unidirectional and perpendicular to the initial plane where spherulites were seeded.

Up to a certain point, such a description might apply to the prisms of $P$. nobilis, and, more generally, to prismatic microstructures in bivalve shells (Ubukata 1994). Several analogies may be found between the two processes. First, similarly to the abiotic competition process, prisms of $P$. nobilis grow in one direction (inward) from an uneven surface, the periostracal layer. Their growth is perpendicular to that surface. Second, Cuif and coworkers (1983a, b) observed that the early stage of prisms formation at the edge of the shell was characterized by the formation of nodules (spherulites) that concentrically develop from a center and completely fill the polygonal spaces delimited by the periprismatic sheaths that form prior mineral deposition. In juvenile specimens of $P$. nobilis, we fully confirm, for each newly 
formed "prism" (at that stage, it looks like a tile), the existence of concentric patterns when the edge of the shell is observed from the outer surface, "through" the thin periostracal layer (Marin, unpublished data). This clearly suggests that nodules (or spherulites) are the first event of mineralization, similarly to what happens during the abiotic competition process. Third, Checa and coworkers observed, in cross sections of $P$. nobilis shells, competition for space, in a very narrow zone, comprised between 50 and $100 \mu \mathrm{m}$ below the periostracal surface (Checa et al. 2005). However, we cannot subscribe to the view of an analogy between the abiotic competition process and the growth of $P$. nobilis prisms for the following reason: as underlined before, the initial "prisms" - or tiles, to be more exact - develop in a preformed honeycomb network, which consequently, antedates the early mineralization. At that stage, no competition for space occurs, since the polygons are already constrained by the periprismatic framework. As underlined by Checa and coworkers (2005) referring to Cuif et al. (1983a, b) the "unmineralized stage extends for at least some $100 \mu \mathrm{m}$ backward from the margin and that empty organic cells (polygons) may attain some $5 \mu \mathrm{m}$ in height at the onset of mineralization." Clearly, the competition for space observed previously seems to intervene at a later stage, during the early elongation phase of the prisms between 50 and $100 \mu \mathrm{m}$. How this competition occurs and why it occurs at that stage is still unclear, but would indicate that the growth of the mineral phase (prisms) catches up that of the organic periprismatic membranes.

In parallel to these observations, a remarkable idea has been developed by Checa and coworkers (2005) for explaining the reason of the polygonal shape of the prisms. These authors observed that the honeycomb-like organic framework has the structure of foam. Foams are gas-in-liquid dispersion mainly stabilized by interfacial tensions, in which the liquid phase is the thin film that separates gas bubbles. In ideal foams, the thin liquid films join at angles of about $120^{\circ}$ to form triple junctions. In the present case, Checa et al. suggested that, rather than foam, the initial stage of the precursors of the mineralization, including the prisms matrix and the extrapallial fluid, may be a liquid-liquid emulsion, i.e., a mixture of two non-miscible liquids. Similarly to foam, an emulsion is patterned by interfacial tension. In this case, the matrix represents the viscoelastic hydrophobic fluid that makes a continuous mesh at the contact of the inner surface of the periostracum. The aqueous discontinuous solution - the extrapallial fluid - would be entrapped in the polygonal cells.

We can try to relate what is described here to the putative functions of calprismin and caspartin, according to their biochemical properties and to their location in the prismatic layer. In our previous study, we have shown that caspartin is intracrystalline and intercrystalline as well (Marin et al. 2007). A similar location seems to occur with calprismin (Narayanappa, in preparation). Because they are extremely acidic, both proteins may act as nucleators of nanocrystals. We can imagine that clusters - rather than films - of caspartin-calprismin complexes may locally catalyze the formation of nanocrystals that self-orient in the forming mesocrystal. The intercrystalline caspartin (and calprismin as well) may play an active role in stabilizing the emulsion, being at the surface of extrapallial fluid droplets, while the more hydrophobic organic network 
polymerizes in a solid and flexible honeycomb-like structure. To summarize, we tentatively dissect the whole sequence of prism formation in $P$. nobilis in short elementary chronological steps.

- In step one, the periostracal layer is secreted by the periostracal groove and hardens when in contact with seawater. The hardening is performed via a quinone-tanning process. Whether the internal surface of the periostracum is "pre-patterned" or not for mineralization is not known. Maybe some spots are "pre-designed" that correspond later to the nucleation centers from which nodules/spherulites grow.

- In step two, a mixture of heterogeneous organic components - the prisms matrix - is secreted together with the precursor fluid that contains mineral ions, between the newly formed periostracum and the mantle. Because some of these components are hydrophobic while the others are hydrophilic, a liquid-liquid emulsion is formed, in close contact with the internal surface of the periostracum. This labile structure, governed by interfacial tension, self-organizes in a viscoelastic mesh composed of polygonal cells. It may be transiently stabilized by acidic proteins at the interface between the two phases.

- In step three, the organic mesh polymerizes similarly to the periostracum, becoming insoluble and flexible.

- In step four, crystal nucleation occurs within each individual polygon, and the newly formed crystalline aggregates, which can be assimilated to nodules/ spherulites, expand concentrically ("hemispherically") until reaching the polygonal boundaries. They form then flat "tiles." Whether the step of crystallization of calcite is preceded by a step of formation of amorphous mineral is not known but can be suspected. The nucleating macromolecules may be acidic proteins such as caspartin or calprismin, or sulfated polysaccharides.

- In step five, while the polygonal boundaries continue to grow in height, the newly formed tiles elongate perpendicularly to the periostracal surface. The extension of periprismatic boundaries may occur by successive accretion of organic elements to their edge. The process involved might be contact recognition. The prism elongation is accomplished "layer-per-layer." For each prism, one "layer" results from the fusion of nano-grains, which are surrounded and crystallographically oriented by acidic proteins (caspartin and calprismin), according to the scheme of Cölfen. Each "layer" can be consequently considered as a flat mesocrystal, which itself fuses with the subjacent mineral receptacle. Whether nano-grains together with their surrounding acidic macromolecules are imported by exocytosis from vesicles of some mantle cells or whether they form directly in the growing structure, at the interface between the mantle cells and the periostracum, is not known.

- In step six, while the prisms continue to grow, competition for space - or something, which looks like it - occurs in the range of 50-100 $\mu \mathrm{m}$ : some slow-growing prisms are absorbed by their fast-growing neighbors. Because the periprismatic boundaries are elastic and deformable, they accompany the lateral expansion of the fast-growing prisms. 
- In step seven, the prisms continue to grow layer per layer, according to the same process described here above. Competition for growth is extremely marginal and most of the prisms grow in parallel. The growth is definitively stopped when the organic interface between the prismatic and the nacreous layers covers the inward surface of the prisms.

In this general scheme, very acidic proteins like caspartin and calprismin may display different functions, and their role is coordinated with that of the hydrophobic constituents of the periprismatic walls. We are fully aware that the steps described above are speculative, and that the true process may be completely different.

\subsubsection{The Nacreous Layer}

Similarly to the formation of prisms, the synthesis of nacre in $P$. nobilis gives rise to a broad range of speculations, which cannot be easily verified. Indeed, our knowledge of the nacre constituents of $P$. nobilis is limited to one single nacre-specific protein, mucoperlin, and most of the knowledge accumulated on nacre derives from other models, such as Nautilus, Pinctada, or Haliotis. Thus, we cannot guarantee that the different aspects of the nacre formation referred below can strictly apply the nacre of $P$. nobilis: as described in Sect. 3.5, the nacre of $P$. nobilis is indeed rather atypical in the bivalvian world, since it represents the row-stack type, and not the brickwall type.

A paper published few years ago by Addadi and coworkers (2006) gives an excellent review of critically important elements for nacre formation. These elements can be summarized as follows: chitin is the structural polymer that preorganizes the interface between the mineralization front and the mantle cells, before mineralization. In nacre, chitin is supposed to define the interlamellar template on which nacre tablets grow. Between successive chitin sheets, a silklike gel composed of hydrophobic proteins is present. This gel also contains acid-soluble proteins that may work as mineral nucleators.

Concerning the process of nacre growth itself, the paper from Addadi et al. (2006) underlines the following aspects: nacre tablets grow from their center, which is enriched in polyanionic polymers (carboxylate-rich, or sulfate-rich). Carboxylate groups may be involved in the nucleation itself, while sulfate groups may concentrate calcium ions at the vicinity of the carboxylate groups (Addadi et al. 1987; Nudelman et al. 2006). The initial minerals formed are amorphous, but they convert to aragonite. Nacre tablets grow vertically, then laterally. By doing so, they entrap acidic proteins and push laterally the hydrophobic gel. When neighboring nacre tablets come in confluence, the squeezed gel polymerizes and forms the intertabular insoluble matrix. Whether nacre tablets grow by heteroepitaxy or by mineral bridges is still unclear and may depend on the studied model. 

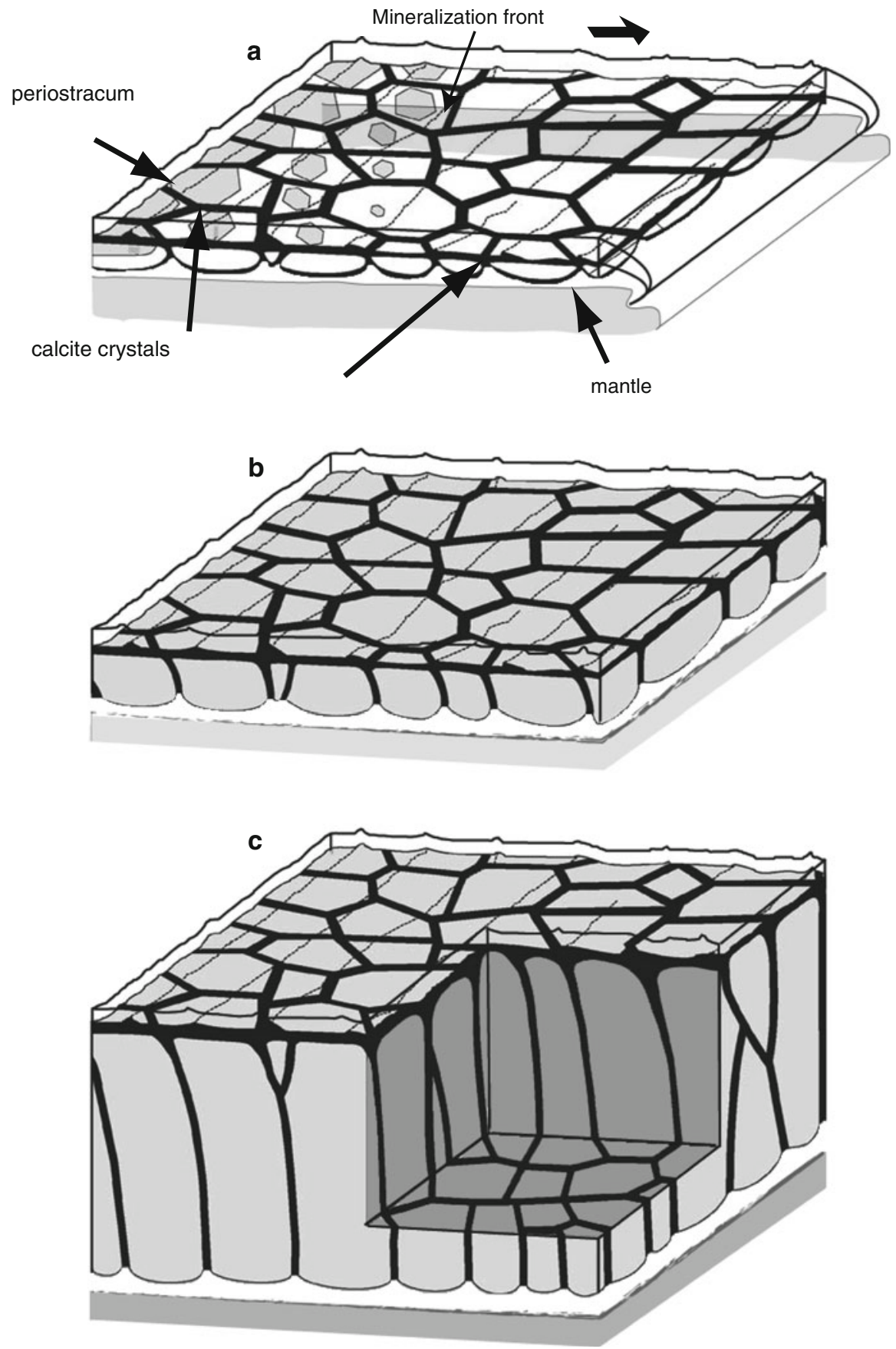

Fig. 13.7 Mode of formation of the calcitic prisms of Pinna nobilis, at different stages (Drawing adapted from a diagram published by Checa et al. (2005, fig. 9 p 6,413). (a) early synthesis stage. 
For the synthesis of the nacre of $P$. nobilis, some elements are seriously missing to give the broad picture: we do not know whether chitin is present, and if so, where it is located. We do not know whether the first minerals formed are amorphous. We do not know whether the row-stack nacre tablets grow by heteroepitaxy or whether they grow on each other via mineral bridges. What remains accurately established concerns the fact that nacre tablets of $P$. nobilis are constituted of nano-grains, as previously shown by Cuif and coworkers (1985). Again, similarly to what happens in the case of the prism, nacre tablets can be considered as mesocrystals, formed by the fusion of crystallographically oriented nanograins. Once more, the concept developed Cölfen seems to be valid and probably corresponds to a general law in biomineralization.

Another important point that partly converges with the Addadi's model described above is the location of mucoperlin. As explained in Sect. 4.3.2, mucoperlin is localized at the periphery of the tablets, in the intertabular matrix, rather than in the interlamellar one. Thus, our explanation is that mucoperlin may be a macromolecular constituent of the gel-like polymer mixture in which nacre tablets grow. When the tablets extend laterally, they push aside mucoperlin, which is consequently squeezed in the intertabular matrix. The single difference between the model and our finding is that mucoperlin is primarily soluble and rather hydrophilic. Thus, mucoperlin is markedly different from the silklike proteins that are supposed to form the hydrophobic gel. Being acidic, one may expect that mucoperlin is involved in nucleating nacre tablets. However, in none of our staining did we observe that mucoperlin was localized within the nacre tablets. What appears extremely consistent is that mucoperlin is specific of the nacreous layer. Thus, we believe that, together with other components, mucoperlin may contribute to the selection of the aragonite polymorph, among other putative functions. More work has however to be done for testing in vitro this hypothesis.

\subsection{Conclusion}

In the present paper, we have tried, as far as we could, to synthesize all the data micro- and nanostructural and biochemical - on the shell of Pinna nobilis and on its acidic macromolecular constituents. Although remarkable advances have been recorded, our story is partial and "holey." Fundamental researches have to be

Fig. 13.7 (continued) The polygonal shape of the periprismatic membranes suggests that they are patterned by interfacial tension of an emulsion. If so, the periprismatic membranes may result from the polymerization of the continuous phase of a liquid-liquid emulsion, consisting of an aqueous discontinuous phase and a hydrophobic continuous one. Note that the periprismatic membranes are formed prior to their mineralization. For each polygon, calcite crystals grow from one center and expand laterally until reaching the periprismatic membranes. (b) later stage. The prisms grow in thickness inward (toward the mantle epithelium), perpendicularly to the periostracal surface. (c) advanced stage. The prisms continue to grow vertically. Locally, crystal competition may occur 
dedicated to the full protein assemblages that shape the prismatic and nacreous layers of Pinna nobilis. This may be performed by combining transcriptomics on mantle tissues that secrete the prismatic and the nacreous layers and proteomics on the shell matrices of the separated layers. In addition, important efforts should also focus on the glycomics aspect of $P$. nobilis shell synthesis and on the supramolecular chemistry that allows the emergence of these beautiful microstructures.

Acknowledgments This chapter is a contribution to the ANR project ACCRO-Earth, ref. BLAN06-2_159971, coordinator Gilles Ramstein, LSCE, Gif/Yvette, for the period 2007-2010. A complementary support was provided by the INTERRVIE program from INSU for the year 2010. Frédéric Marin thanks Professor Jean-Pierre Gauthier for providing the SEM picture of newly formed nacre tablets (Fig. 13.3f) and for scrupulous rereading. Alain Godon (UMR CNRS 5561) is also acknowleged for redesigning Fig. 13.7 from the paper of Checa et al. (2005).

\section{References}

Addadi L, Moradian J, Shay E, Maroudas NG, Weiner S (1987) A chemical model for the cooperation of sulfates and carboxylates in calcite crystal nucleation: relevance to biomineralization. Proc Natl Acad Sci USA 84:2732-2736

Addadi L, Joester D, Nudelman F, Weiner S (2006) Mollusk shell formation: a source of new concepts for understanding biomineralization processes. Chem Eur J 12:980-987

Afdhal NH, Ostrow JD, Koehler R, Niu N, Groen AK, Veis A, Nunes DP, Offner GD (1995) Interaction of bovine gallbladder mucin and calcium-binding protein: effect on calcium phosphate precipitation. Gastroenterology 109:1661-1672

Akiyama M (1966) Conchiolin-constituent amino acids and shell structures of bivalved shells. Proc Jpn Acad 2:800-805

Bafna S, Singh AP, Moniaux N, Eudy JD, Meza JL, Batra SK (2008) MUC4, a multifunctional transmembrane glycoprotein, induces oncogenic transformation of NIH3T3 mouse fibroblast cells. Cancer Res 68:9231-9238

Biedermann W (1901) Untersuchungen über Bau und Entstehung der Molluskenschalen. Jena Z Naturwiss 36:1-164

Boggild OB (1930) The shell structure of the mollusks. D Kgl Danske Vidensk Selsk Skrifter, Naturvidensk Og Mathem Afd, 9. Raekke, II.2:231-326

Bowerbank JS (1844) On the structure of the shell of molluscous and conchiferous animals. Trans Microsc Soc Lond 1:123-154

Bricteux-Grégoire S, Florkin M, Grégoire C (1968) Prism conchiolin of modern or fossil molluscan shells. An example of protein paleization. Comp Biochem Physiol 24:567-572

Brisou J (1985) Les coquillages dans l'histoire des hommes. Ed. Ouest France, p 140

Cabanellas-Reboredo M, Deudero S, Alos J, Valencia JM, March D, Hendriks IE, Alvarez E (2009) Recruitment of Pinna nobilis (Mollusca: Bivalvia) on artificial structures. Mar Biodiv Rec 2:1-5

Carpenter WB (1844) Report on the microscopic structure of shells. Rep Brit Assoc Adv Sci 14th meeting, pp 1-24

Carter JG (1990) Skeletal Biomineralization: Patterns, Processes and Evolutionary Trends, vol I and II "Atlas and index". Van Nostrand Reinhold, New York

Carter JG, Clark GR II (1985) Classification and phylogenetic significance of molluscan shell microstructure. In: Broadhead TW (ed) Mollusks - Notes for a short course, University of Tennessee, Dept of Geological Sciences, Studies in Geology 13, pp 50-71 
Cayeux L (1916) Introduction à l'étude pétrographique des roches sédimentaires: mémoire pour servir à l'explication de la carte géologique détaillée de la France, vol $1 \& 2$. Ministère des Travaux Publics/Imprimerie Nationale, Paris

Centoducati G, Tarsitano E, Bottalico A, Marvulli M, Lai OR, Crescenzo G (2007) Monitoring of the endangered Pinna nobilis Linné 1758 in the Mar Grande of Taranto (Ionian sea, Italy). Environ Monit Assess 131:339-347

Checa AG, Rodriguez-Navarro AB, Esteban-Delgado FJ (2005) The nature and formation of calcitic columnar prismatic shell layers in pteriomorphian bivalves. Biomater 26:6404-6414

Cölfen H (2007) Non classical crystallization. In: Arias JL, Fernandez MS (eds) Biomineralization, from paleontology to materials science. Editorial Universitaria, Santiago de Chile, pp 515-526

Cölfen H, Antonietti M (2005) Mesocrystals: inorganic superstructures made by highly parallel crystallization and controlled alignment. Angew Chem Int Ed 44:5576-5591

Collins MJ, Muyzer G, Curry GB, Sandberg P, Westbroek P (1991) Macromolecules in brachiopod shells: characterization and diagenesis. Lethaia 24:387-397

Cosentino A, Giacobbe S (2006) Shell ornament in Pinna nobilis and Pinna rudis (Bivalvia: Pteriomorpha). J Conchiol 39:135-140

Cosentino A, Giacobbe S (2007a) Aspects of epizoobiontic mollusk assemblages on Pinna shells. Composition and structure. Cah Biol Mar 48:187-197

Cosentino A, Giacobbe S (2007b) Aspects of epizoobiontic mollusk assemblages on Pinna shells. II. Does the Mediterranean $P$. nobilis represent an isle of biodiversity? Cah Biol Mar 49:161-173

Crenshaw MA (1972) The soluble matrix from Mercenaria mercenaria shell. Biomineralization 6:6-11

Cuif JP, Raguideau A (1982) Observation sur l'individualité cristallographique des prismes de Pinna nobilis L. C R Acad Sci Paris, sér II, 295:415-418

Cuif JP, Dauphin Y, Denis A, Gaspard D, Keller JP (1980) Continuité et périodicité du réseau organique intraprismatique dans le test de Pinna muricata Linné (Lamellibranche). C R Séanc Acad Sci Paris, sér D, 290:759-762

Cuif JP, Denis A, Gaspard D (1981) Recherche d'une méthode d'analyse ultrastructurale des tests carbonatés d'invertébrés. Bull Soc Geol Fr 9, XXIII, 5:525-534

Cuif JP, Dauphin Y, Denis A, Gaspard D, Keller JP (1983a) Etude des caractéristiques de la phase minérale dans les structures prismatiques du test de quelques mollusques. Bull Mus Natn Hist Nat Paris 4e sér. 5, section A, 3:679-717

Cuif JP, Denis A, Raguideau A (1983b) Observations sur les modalités de mise en place de la couche prismatique du test de Pinna nobilis L. par l'étude des caractéristiques de la phase minérale. Haliotis 13:131-141

Cuif JP, Denis A, Flamand D, Frérotte B (1985) Etude ultrastructurale de la transition prismes/ nacre dans le test de Pinna nobilis L (mollusque, lamellibranche). Sci Rep Port Cros natl Park Fr 11:95-107

Cuif JP, Dauphin Y, Flamand D, Frérotte B, Gautret P (1986) La mesure localisée du taux de soufre comme indicateur de l'origine et de l'état diagénétique des biocristaux carbonatés. C R Acad Sci Paris, sér II, 303(3):251-256

Cuif JP, Dauphin Y, Denis A, Gautret P, Lawniczak A, Raguideau A (1987a) Résultats récents concernant l'analyse des biocristaux carbonatés; implications biologiques et sédimentologiques. Bull Soc Geol Fr 8, t III, 2:269-288

Cuif JP, Flamand D, Frérotte B, Chabin A, Raguideau A (1987b) Fractionnement de la matrice protéique intraprismatique chez Pinna nobilis L et composition en acides aminés des différentes phases. C R Acad Sci Paris, sér II, 304(9):475-478

Cuif JP, Denis A, Frérotte B, Rekkab D (1988a) Gradient de concentration d'élements mineurs et séquence microstructurale dans le test de mollusques. C R Acad Sci Paris, sér II, 307:837-842 
Cuif JP, Dauphin Y, Gautret P (1988b) Corrélation entre l'organisation cristallographique des unités microstructurales formant le test des Mollusques et la masse moléculaire moyenne de leur phase organique soluble. C R Acad Sci Paris, sér II, 307:1943-1948

Cuif JP, Gautret P, Marin F (1991) Correlation between the size of crystals and the molecular weight of organic fractions in the soluble matrices of mollusc, coral and sponge carbonate skeletons. In: Suga S, Nakahara H (eds) Mechanisms and Phylogeny of Mineralization in Biological Systems. Springer, Tokyo, pp 391-395

Dauphin Y (2002) Comparison of the soluble matrices of the calcitic prismatic layer of Pinna nobilis (Mollusca, Bivalvia, Pteriomorpha). Comp Biochem Physiol A 132:577-590

Dauphin Y (2003) Soluble organic matrices of the calcitic prismatic shell layers of two pteriomorphid bivalves: Pinna nobilis and Pinctada margaritifera. $\mathrm{J}$ Biol Chem 278:15168-15177

Dauphin Y, Cuif JP, Doucet J, Salomé M, Susini J, Williams CT (2003) In situ chemical speciation of sulfur in calcitic biominerals and the simple prism concept. J Struct Biol 142:272-280

De Bournon E (1808) Traité complet de la chaux carbonatée et de l'aragonite, William Phillips (ed.) vol I. London

De Gaulejac B (1993) Etude écophysiologique du mollusque bivalve méditerranéen Pinna nobilis L. Reproduction, croissance, respiration. Thèse $3^{\text {ème }}$ cycle, Université d'Aix-Marseille III, p 220

De Gaulejac B, Vicente N (1990) Ecologie de Pinna nobilis (L.) mollusque bivalve sur les côtes de Corse. Essais de transplantation et expériences en milieu contrôlé. Haliotis 10:83-100

De Gaulejac B, Henry M, Vicente N (1995a) An ultrastructural study of gametogenesis of the marine bivalve Pinna nobilis (Linnaeus 1758) I. Oogenesis. J Mollus Stud 61:375-392

De Gaulejac B, Henry M, Vicente N (1995b) An ultrastructural study of gametogenesis of the marine bivalve Pinna nobilis (Linnaeus 1758) II. Spermatogenesis. J Mollus Stud 61:393-403

Esteban-Delgado FJ, Harper EM, Checa AG, Rodriguez-Navarro AB (2008) Origin and expansion of foliated microstructures in pteriomorph bivalves. Biol Bull 214:153-165

Evans JS (2008) "Tuning in" to mollusk shell nacre- and prismatic-associated protein terminal sequences. Implications for biomineralization and the construction of high performance inorganic-organic composites. Chem Rev 108:4455-4462

Foulquié M, Dupuy de la Grandrive R (2003) Mise en place d'un suivi des grandes nacres (Pinna nobilis) dans la zone Natura 2000 des "Posidonies du Cap d'Agde", Hérault, France. In: Vicente N (ed) Mémoires de l'Institut Océanographique Paul Ricard, $1^{\mathrm{er}}$ Séminaire International sur la grande Nacre de Méditerranée : Pinna nobilis, 10-12 Octobre 2002, Institut Océanographique Paul Ricard, pp 49-55

Frémy ME (1855) Recherches chimiques sur les os. Annales Chim Phys, $3^{\text {ème }}$ sér. 43:47-107

Frérotte B (1987) Etude de l'organisation et de la composition des biocristaux du test des lamellibranches. Thèse de $3^{\text {ème }}$ Cycle, Laboratoire de Paléontologie, Université Paris XI, Orsay

Garcia-March JR (2003) Contribution to the knowledge of the status of Pinna nobilis (L.) 1758 in Spanish Coasts. In: Vicente N (ed) Mémoires de 1'Institut Océanographique Paul Ricard, $1^{\text {er }}$ Séminaire International sur la grande Nacre de Méditerranée : Pinna nobilis, 10-12 Octobre 2002, Institut Océanographique Paul Ricard, pp 29-41

Garcia-March JR, Carrascosa AMG, Pena AL (2002) In situ measurement of Pinna nobilis shells for age and growth studies: a new device. Mar Ecol 23:207-217

Garcia-March JR, Garcia-Carrascosa AM, Pena Cantero AL, Wang YG (2007) Population structure, mortality and growth of Pinna nobilis Linnaeus, 1758 (Mollusca, Bivalvia) at different depths in Moraira bay (Alicante, Western Mediterranean). Mar Biol 150:861-871

Gauthier JP, Caseiro J, Lasnier B (1994) Les perles rouges de Pinna nobilis. Revue de Gemmologie, A.F.G., 118:2-4; 119:2-4

Giacobbe S (2002) Epibiontic mollusc communities on Pinna nobilis L. (Bivalvia, Mollusca). J Nat Hist 36:1385-1396

Giribet G (2008) Bivalvia. In: Ponder WF, Lindberg DR (eds) Phylogeny and Evolution of the Mollusca. University of California Press, Berkeley, pp 105-141 
Grases F, Llobera A (1998) Experimental model to study sedimentary kidney stones. Micron 29:105-111

Gray JE (1835) Remarks on the difficulty of distinguishing certain genera of testaceous mollusca by their shell alone, and on the anomalies in regard to habitation observed in certain species. Phil Trans R Soc Lond 125:301-310

Grégoire C (1967) Sur la structure des matrices organiques des coquilles de mollusques. Biol Rev 42:653-688

Grégoire C (1972) Structure of the molluscan shell. In: Florkin M, Scheer BT (eds) Chemical Zoology, vol VII, mollusca. Academic, New York, pp 45-102

Grigor'ev DP (1965) Ontogeny of Minerals. Israel Program for Scientific Translation, Jerusalem, $250 \mathrm{pp}$

Henry M, Vicente N, Houache N (1992) Caractérisation des hémocytes d'un mollusque bivalve marin, la nacre, Pinna nobilis L. 1758. In: Aspects Récents de la Biologie des Mollusques, Ifremer, Actes de Colloques 13, pp 97-106

Jackson DJ, McDougall C, Green K, Simpson F, Wörheide G, Degnan BM (2006) A rapidly evolving secretome builds and patterns a sea shell. BMC Biol 4:40-49

Karampelas S, Gauthier JP, Fritsch E, Notari F (2009) Characterization of some pearls of the Pinnidae family. Gems Gemol 45:221-223

Karny H (1913) Optische Untersuchungen zur Aufklärung der Struktur der Muschenschalen. I. Aviculidae, II. Unionidae. Sitzungsberichte der Akademie der Wissenschaften, Mathematisch-Naturwissenschaftliche Klasse. Wien 122:207-259

Katsanevakis S (2007) Growth and mortality rates of the fan mussel Pinna nobilis in Lake Vouliagmeni (Korinthiakos Gulf, Greece): a generalized additive modelling approach. Mar Biol 152:1319-1331

Katsanevakis S, Thessalou-Legaki M (2009) Spatial distribution, abundance and habitat use of the protected fan mussel Pinna nobilis in Souda Bay, Crete. Aquat Biol 8:45-54

Keller JP (1981) Le dégagement du matériel minéral des tests d'invertébrés (Bivalves) par protéolyse enzymatique de la trame organique. Geobios 14:269-273

Keller JP, Dauphin Y (1983) Methodological aspects of the ultrastructural analysis of the organic and mineral components in mollusc shells. In: Westbroek P, De Jong EW (eds) Biomineralization and biological metal accumulation. D Reidel Publishing, Dordrecht, pp 255-260

Kervadec G (1990) Estimation de la validité taxonomique du critère minéralogique par l'analyse des phases organiques solubles des biocristaux carbonatés des mollusques. Thèse de $3^{\text {ème }}$ Cycle, Laboratoire de Paléontologie, Université Paris XI, Orsay

Kniprath E (1981) Ontogeny of the molluscan shell field. Zool Scr 10:61-79

Kretsinger RH (1976) Calcium-binding proteins. Annu Rev Biochem 45:239-266

Lechene de la Porte P, Domingo N, van Wijland M, Groen AK, Ostrow JD, Lafont H (1996) Distinct immuno-localization of mucin and other biliary proteins in human cholesterol gallstones. J Hepatol 25:339-348

Leydolt F (1856) Über die Struktur und Zusammensetzung der Krystalle des prismatischen Kalkhaloides nebst einem Anhang über die Struktur der kalkigen Teile einiger wirbellosen Tiere. Sitzungsberichte Mathematisch Naturwiss Klasse Kaiserlichen Akad Wiss Wien 19:10-32

Maeder F, Halbeisen M (2001) Muschelseide: Auf der Suche nach einel vergessenen Material. Waffen Kostumkunde 43:33-41

Mao Che L, Golubic S, Le Campion-Alsumard T, Payri CE (2001) Developmental aspects of biomineralization in the polynesian pearl oyster Pinctada margaritifera var. cumingii. Oceanol Acta 24:S37-S49

Marin F (1992). Essai de caractérisation chromatographique et immunologique des constituants organiques associés aux biocristaux carbonatés des squelettes de mollusques, cnidaires et spongiaires. Thèse de $3^{\text {ème }}$ Cycle, Laboratoire de Paléontologie, Université Paris XI, Orsay

Marin F (2003) Molluscan shell matrix characterization by preparative SDS-PAGE. Sci World J 3:342-347 
Marin F (2009) Biominéralisation de la coquille des mollusques : origine, évolution, formation. Mémoire d'Habilitation à Diriger des Recherches. Université de Bourgogne, Dijon, p 243

Marin F, Luquet G (2005) Molluscan biomineralization: the proteinaceous shell constituents of Pinna nobilis L. Mater Sci Eng C 25:105-111

Marin F, Luquet G (2007) Unusually acidic proteins in biomineralization. In: Baeuerlein E (ed) Handbook of Biomineralization, vol 1, The Biology of Biominerals Structure Formation. Wiley-VCH, Weinheim, pp 273-290, Chapter 16

Marin F, Muyzer G, Dauphin Y (1994) Caractérisation électrophorétique et immunologique des matrices organiques solubles de deux Bivalves Ptériomorphes actuels, Pinna nobilis L. et Pinctada margaritifera (L.). C R Acad Sci Paris II 318:1653-1659

Marin F, Gillibert M, Wesbroek P, Muyzer G, Dauphin Y (1999) Evolution: disjunct degeneration of immunological determinants. Geol Mijnbouw 78:135-139

Marin F, Corstjens P, de Gaulejac B, de Vrind-De JE, Westbroek P (2000) Mucins and molluscan calcification: molecular characterization of mucoperlin, a novel mucin-like protein of the nacreous shell-layer of the fan mussel Pinna nobilis (Bivalvia, Pteriomorphia). J Biol Chem 275:20667-20675

Marin F, Pereira L, Westbroek P (2001) Large-scale purification of molluscan shell matrix. Prot Expres Purif 23:175-179

Marin F, de Groot K, Westbroek P (2003a) Screening molluscan cDNA expression libraries with anti-shell matrix antibodies. Prot Expres Purif 30:246-252

Marin F, Westbroek P, de Groot K (2003b) The proteinaceous constituents of the shell of Pinna nobilis L. In: Vicente $\mathrm{N}$ (ed) Mémoires de l'Institut Océanographique Paul Ricard, $1^{\mathrm{er}}$ Séminaire International sur la grande Nacre de Méditerranée: Pinna nobilis, 10-12 Octobre 2002, Institut Océanographique Paul Ricard, pp 77-90

Marin F, Amons R, Guichard N, Stigter M, Hecker A, Luquet G, Layrolle P, Alcaraz G, Riondet C, Westbroek P (2005) Caspartin and calprismin, two proteins of the shell calcitic prisms of the Mediterranean fan mussel Pinna nobilis. J Biol Chem 280:33895-33908

Marin F, Morin V, Knap F, Guichard N, Marie B, Luquet G, Westbroek P, Medakovic D (2007a) Caspartin: thermal stability and occurrence in mollusk calcified tissues. In: Arias JL, Fernandez MS (eds) Biomineralization, from paleontology to materials science. Editorial Universitaria, Santiago de Chile, pp 281-288

Marin F, Pokroy B, Luquet G, Layrolle P, de Groot K (2007b) Protein mapping of calcium carbonate biominerals by immunogold. Biomater 28:2368-2377

Marin F, Luquet G, Marie B, Medakovic D (2008) Molluscan shell proteins: primary structure, origin and evolution. Curr Top Dev Biol 80:209-276

Masuda F, Hirano M (1980) Chemical composition of some modern marine pelecypod shells. Sci Rep Inst Geosci Univ Tsukuba section B1:163-177

Maurer P, Hohenester E, Engel J (1996) Extracellular calcium-binding proteins. Curr Opin Cell Biol 8:609-617

Medakovic D (2000) Carbonic anhydrase activity and biomineralization in embryos, larvae and adult blue mussels Mytilus edulis L. Helgol Mar Res 54:1-6

Medioni E, Vicente N (2003) Etude de la cinétique des populations de Pinna nobilis L. 1758 sur le littoral méditerranéen français. In: Vicente N (ed) Mémoires de l'Institut Océanographique Paul Ricard, $1^{\text {er }}$ Séminaire International sur la grande Nacre de Méditerranée: Pinna nobilis, 10-12 Octobre 2002, Institut Océanographique Paul Ricard, pp 43-48

Meyer-Lüeckel H, Tschoppe P, Hopfenmüller W, Stenzel WR, Kielbassa AM (2006) Effect of polymers used in saliva substitutes on demineralized bovine enamel and dentin. Am J Dent 19:308-312

Moreteau JC, Vicente N (1982) Evolution d'une population de Pinna nobilis L. (Mollusca, Bivalvia). Malacologia 22:341-345

Mutvei H (1970) Ultrastructure of the mineral and organic components of molluscan nacreous layers. Biomineral Res Rep 2:48-72 
Muyzer G, Westbroek P, De Vrind JPM, Tanke J, Vrijheid T, De Jong EW, Bruning JW, Wehmiller JF (1984) Immunology and organic geochemistry. Org Geochem 6:847-855

Nakahara H, Kakei M, Bevelander G (1980) Fine structure and amino acid composition of the organic "envelope" in the prismatic layer of some bivalve shells. Venus 39:167-177

Nieuw-Amerongen AV, Oderkerk CH, Veerman ECI (1989) Interaction of human salivary mucins with hydroxyapatite. J Biol Buccale 17:85-92

Nudelman F, Gotliv BA, Addadi L, Weiner S (2006) Mollusk shell formation: mapping the distribution of organic matrix components underlying a single aragonite tablet in nacre. J Struct Biol 153:176-187

Oaki Y, Imai H (2005) The hierarchical architecture of nacre and its mimetic material. Angew Chem Int Ed Engl 44:6571-6575

Palmer AR (1992) Calcification in marine molluscs: how costly is it? Proc Natl Acad Sci USA 89:1379-1382

Pokroy B, Fitch AN, Marin F, Kapon M, Adir N, Zolotoyabko E (2006) Anisotropic lattice distorsions in biogenic calcite induced by intra-crystalline organic molecules. J Struct Biol 155:96-103

Pokroy B, Kapon M, Marin F, Adir N, Zolotoyabko E (2007) Protein-induced, previously unidentified twin form of calcite. Proc Natl Acad Sci USA 104:7337-7341

Rabaoui L, Tlig-Zouari S, Ben Hassine OK (2007) Description de la faune épibionte de Pinna nobilis sur les côtes nord et est de la Tunisie. Rapp Comm Int Mer Medit 38:578

Rabaoui L, Tlig-Zouari S, Ben Hassine OK (2008) Distribution and habitat of the fan mussel Pinna nobilis Linnaeus, 1758 (Mollusca: Bivalvia) along the northern and eastern Tunisian coasts. Cah Biol Mar 49:67-78

Rabaoui L, Tlig-Zouari S, Cosentino A, Ben Hassine OK (2009) Associated fauna of the fan shell Pinna nobilis (Mollusca: Bivalvia) in the northern and eastern Tunisian coasts. Sci Mar 73:129-141

Ranson G (1952) Les huîtres et le calcaire. Calcaire et substratum organique chez les mollusques et quelques autres invertébrés marins. C R Acad Sci Paris 234:1485-1487

Ranson G (1966) Substratum organique et matrice organique des prismes de la couche prismatique de la coquille de certains mollusques lamellibranches. C R Acad Sci Paris 262:1280-1282

Riva A (2003) Approche méthodologique de quelques paramètres bioénergétiques chez Pinna nobilis. In: Vicente N (ed) Mémoires de l'Institut Océanographique Paul Ricard, $1{ }^{\text {er }}$ Séminaire International sur la grande Nacre de Méditerranée : Pinna nobilis, 10-12 Octobre 2002, Institut Océanographique Paul Ricard, pp 91-101

Roche J, Ranson G, Eysseric-Lafon M (1951) Sur la composition des scléroprotéines des coquilles des mollusques (conchiolines). C R Séanc Soc Biol 145:1474-1477

Römer O (1903) Untersuchungen über den feineren Bau einiger Muschelschalen. Z Wiss Zool 75:437-472

Rose G (1858) Über die heteromorphen Zustände der Kohlensauren Kalkerde. II. Vorkommen des Aragonits und Kalkspaths in der organischen Natur: Physikalische Abhandlungen der Königlichen Akademie der Wissenschaften zu Berlin aus dem Jahre 1858:63-111

Schmidt WJ (1923) Bau und Bildung der Perlmuttermasse. Zoologische Jahrbücher Abteilung Anat Ontogenie Tiere 45:1-148

Schmidt WJ (1924) Die Bausteine des Tierkörpers in polarisiertem Lichte. F. Cohen, Bonn

Schmidt WJ (1932) Studien über Pinnaperlen. I. Über Prismenperlen von Pinna nobilis. Z Morph Ökol Tiere Abt A 25:235-277

Siletic T, Peharda M (2003) Population study of the fan shell Pinna nobilis L. in Malo and Veliko Jezero of the Mljet National Park (Adriatic Sea). Sci Mar 67:91-98

Simkiss K, Wilbur KM (1989) Biomineralization. Cell biology and mineral deposition. Academic, New York

Steiner G, Hammer S (2000) Molecular phylogeny of the Bivalvia inferred from 18 S rDNA sequences with particular reference to the Pteriomorphia. In: Harper EM, Taylor JD, Crame JA 
(eds) Evolutionary biology of the Bivalvia. Geological Society, London, pp 11-29, Geological Society Special Publication, 177

Sudo S, Fujikawa T, Nagakura T, Ohkubo T, Sakagushi K, Tanaka M, Nakashima K (1997) Structures of mollusc shell framework proteins. Nature 387:563-564

Tabak LA (1995) In defense of the oral cavity: structure, biosynthesis, and function of salivary mucins. Annu Rev Physiol 57:547-564

Tabak LA, Levine MJ, Jain NK, Bryan AR, Cohen RE, Monte LD, Zawacki S, Nancollas GH, Slomiany A, Slomiany BL (1985) Adsorption of human salivary mucins to hydroxyapatite. Arch Oral Biol 30:423-427

Taylor JD, Kennedy WJ, Hall A (1969) The shell structure and mineralogy of the Bivalvia. Introduction. Nuculacea-Trigonacea. Bull Brit Mus Nat Hist Zool Lond supplem 3:1-125

Ubukata T (1994) Architectural constraints on the morphogenesis of prismatic structure in Bivalvia. Palaeontology 37:241-261

Vicente N (2003) La grande nacre de Méditerranée Pinna nobilis. Présentation générale. In: Vicente N (ed) Mémoires de l'Institut Océanographique Paul Ricard, ${ }^{\text {er }}$ Séminaire International sur la grande Nacre de Méditerranée : Pinna nobilis, 10-12 Octobre 2002, Institut Océanographique Paul Ricard, pp 7-16

Vicente N, Riva A, Butler A (1992) Etude expérimentale préliminaire sur les échanges gazeux chez Pinna nobilis. In : Aspects Récents de la Biologie des Mollusques, Ifremer Brest, Actes de Colloques 13, pp 187

Wada K (1961) Crystal growth of molluscan shells. Bull Natl Pearl Res Lab 7:703-828

Wada K (1972) Nucleation and growth of aragonite crystals in the nacre of some bivalve molluscs. Biominer Res Rep 6:141-159

Wada K (1980) Initiation of mineralization in bivalve mollusc. In: Omori M, Watabe N (eds) The mechanism of biomineralization in animals and plants. Tokay University Press, Tokyo, pp 79-92

Weiner S (1983) Mollusk shell formation - Isolation of two organic matrix proteins associated with calcite deposition in the bivalve Mytilus californianus. Biochemistry 22:4139-4145

Weiner S, Hood L (1975) Soluble proteins of the organic matrix of mollusc shells: a potential template for shell formation. Science 190:987-989

Weiss IM, Tuross N, Addadi L, Weiner S (2002) Mollusc larval shell formation: amorphous calcium carbonate is a precursor phase for aragonite. J Exp Zool 293:478-491

Wetzel G (1900) Die organischen Substanzen der Schaalen von Mytilus und Pinna. Z. Phys Chem 29:386-410

Wheeler AP, Rusenko KW, Sikes CS (1988) Organic matrix from carbonate biomineral as a regulator of mineralization. In: Sikes CS, Wheeler AP (eds) Chemical aspects of regulation of mineralization. University of South Alabama Publication Service, Mobile, Alabama, pp 9-13

Wise SW (1970) Microarchitecture and mode of formation of nacre (mother-of-pearl) in pelecypods, gastropods, and cephalopods. Eclog Geol Helvet 63:775-797

Zavodnik D (1967) Contribution to the ecology of Pinna nobilis L. (Moll. Bivalvia) in the Northern Adriatic Sea. Thalass Yugol 3:93-102

Zolotoyabko E, Caspi EN, Fieramosca JS, Von Dreele RB, Marin F, Mor G, Addadi L, Weiner S, Politi Y (2010) Differences between bond lengths in biogenic and geological calcite. Cryst Growth Des 10:1207-1214 